\title{
The Characteristics of FDI Activities Located in Different Host Regions - A Study Based on Firm-Level Data ${ }^{a}$
}

\author{
Spyros Arvanitis $^{\mathrm{b}}$, Heinz Hollenstein ${ }^{\mathrm{c}}$ and Tobias $^{\text {Stucki }}{ }^{\mathrm{d}}$
}

Keywords: Foreign Direct Investment; Global Location Portfolios; Intra-Firm Trade JEL classification: F2

\section{Introduction}

Foreign direct investments (FDI) have grown at high rates over the last three decades. Correspondingly, the theoretical and empirical literature dealing with a multitude of aspects of FDI strongly expanded (for a detailed overview see, e.g., Dunning and Lundan, 2008). However, there are some topics for which empirical evidence remains relatively scarce, in particular as far as it is based on the analysis of firm data.

One particular gap pertains to the analysis of the characteristics of FDI activities in specific host regions based on firm-level data. In a recent survey of the literature on location and MNEs CANTwell (2008) emphasized the issue of "firm-location interactions". In particular he pointed out (p. 38) that in analyzing location choice it does not suffice to account for the diversity of locational environments but it is necessary to also consider the diversity (thus the heterogeneity) of firms. Taking up this conclusion, we investigate in this paper a set of firm and FDI characteristics that are hypothesized to drive an MNE to choose for its foreign investments ${ }^{1}$ a specific host region.

a Acknowledgments: This article has greatly benefited from the guidance of the Editor, Volker Grossmann, and the comments and suggestions of two anonymous reviewers of this journal. The research has been supported by the Swiss State Secretariat of Economics (Seco).

b ETH Zurich, KOF Swiss Economic Institute, Leonhardstrasse 21, CH-8092 Zurich, Phone: +41446325168, email: arvanitis@kof.ethz.ch

c ETH Zurich, KOF Swiss Economic Institute, Leonhardstrasse 21, CH-8092 Zurich, Phone: +4144632 53 29, email: hollenstein@kof.ethz.ch

d Corresponding author; ETH Zurich, KOF Swiss Economic Institute, Leonhardstrasse 21, CH-8092 Zurich, Phone: +41 4463263 07, email: stucki@kof.ethz.ch

1 In this paper, the term FDI pertains to all forms of equity-based foreign activities of domestic companies, i.e. wholly-owned foreign affiliates, majority/minority stakes in foreign firms; equity-based joint ventures/alliances with foreign partners. 
In this paper we use firm-level data in order to explain the probability that a firm locates FDI activities in a certain region. We investigate the relationship between the FDI location probability and a series of firm characteristics that according to literature are associated with the FDI propensity. This allows us to identify differences in the characteristics of firms at time of observation, depending on where they have located their FDI activities. More concretely we will consider the following three bundles of firm characteristics: (a) the type of FDI (vertical, horizontal, distribution-oriented), (b) the relevance of FDI experience, and (c) the importance of the firm's capacity to innovate.

So far, the choice among alternative FDI locations has primarily been investigated with country data (see, e.g., Blonigen and Wang, 2005; Brainard, 1993; Eaton and Tamura, 1994; Eкholm, 1998; Duanmu, 2012, 2014; Kang and Jiang, 2012; specifically for services: Py and Нatem, 2009) or with subnational data (see, e.g., Guimaraes et al., 2000; Barrios et al., 2006; Basile et al., 2008). These studies analyze how country/regional characteristics affect FDI flows. BlONigen and WANG (2005), for example, find substantial differences in the factors determining FDI in less developed host countries as compared to those in advanced economies. However, macro-level studies do not take into account the heterogeneity of firms within a country/region. Therefore a more disaggregated analysis of the choice of FDI locations is required, which in the optimal case combines information on the parent company, its foreign affiliates and the relationship between them.

The scarce firm-level literature analyzing the structural characteristics of FDI located in different host regions can be divided into two groups. The first group of studies deals with the differences among many host regions with respect to one or very few characteristics. Davidson (1980), for example, investigates the relationship between FDI experience of U.S.-based MNEs and their FDI locations. Shatz and Venables (2000) analyze whether the share of U.S. and Japanese affiliate production that is sold back to the home country differs between host countries. Chen and Moore (2010) analyze whether total factor productivity of French parent firms differs between FDI locations. Demirbag and Glaister (2010) investigate whether FDI experience, project type (research vs. development) and industry affiliation differ among five target regions characterized by different location characteristics ( $R \& D$ wages, availability of researchers, etc.). SiedsChlag et al. (2013) examined the factors that determine the location choice of R\&D activities of European multinational firms in the period 1999-2006.

The second category of firm-level studies in this area considers in more detail the characteristics of firms and FDI at the expense of the number of host countries included in the analysis. Makino et al. (2004) investigate whether some 
specific characteristics of Japanese parent companies (R\&D intensity, prior host country experience, size) and their foreign subsidiaries (size, age, equity ownership) differ between FDI in developed countries and those in less advanced economies. Further, Aw and LeE (2008) compare some characteristics of Taiwanese MNEs investing in China with those doing so in the USA. More specifically, they focus on differences with respect to productivity and innovation activity of the parent firms.

We are able to differentiate between host regions in more detail than in the second category of previous studies. Concretely, we are able to distinguish nine host regions (EU15/EFTA, Eastern Europe, Southeast Europe, Russia, North America, Latin America, China, Asian Tigers and Southeast Asia including India) ${ }^{2}$, which differ, in the first place, in terms of demand-, cost- and knowledge-related location advantages.

At the same time, we can account for the characteristics of FDI activities at firm level in a more differentiated way than it is the case in most previous investigations of the first group. ${ }^{3}$ We are in a position to do so as we have at our disposal a unique firm-level data set (cross-section for 2010, 1921 firms) containing for a large number of Swiss MNEs information. More specifically, the data includes information to the parent company (first-time FDI activity, firm age, R\&D intensity, share of employees with a degree at the tertiary level, firm size, industry affiliation), the foreign subsidiaries (type of business function, objectives of the functional units based on a number of motives of foreign activity), and the two-way transactions between the parent company and its foreign affiliate(s).

This information allows us to econometrically analyze how the firm characteristics differ, depending on where the firms have located their FDI activities. Concretely we will estimate three different models. In our basic model (model I) our focus is on differences with respect to FDI experience (measured by time of first FDI activities and firm age) and the firms' capability to innovate (measured by R\&D intensity and share of tertiary level employees). In a second model we add variables for intra-firm trade flows in order to reveal the role of different types of FDI (vertical, horizontal, distribution-oriented FDI) in detail (model II). In a third model, we use variables for different FDI motives in order to analyze the relevance of production oriented FDI in more detail (model III). Multivariate probit estimators are used throughout the econometric estimations.

2 In 2009 , these regions held more than $95 \%$ of the total foreign capital stock of Swiss companies.

3 An earlier version of this paper is found in Arvanitis et al. (2011), chapter 4 and it is part of this study, which was financed by the State Secretariat for Economic Affairs (SECO). 
The estimation results indicate that there is low correlation between a firm's innovative potential and FDI experience, respectively, and the location of their FDI activities. However, the type of FDI significantly differs between the regions. For example, we find that Asia is a very heterogeneous host region. Some parts (sub regions) are attractive for cheap production activities (indicating vertical FDI in Southeast Asia/India), the more advanced "tiger countries" are important sales markets (indicating horizontal FDI), whereas China receives a mix of vertical and, due to its large and fast-growing market, horizontal FDI.

The remainder of the paper is organized as follows: Section 2 provides a detailed characterization of the regions hosting FDI. In Section 3 we present the conceptual background of the analysis and derive the hypotheses regarding the role of firm characteristics for locating activities in the different regions (Section 3). In Section 4 we describe the database, and in Section 5 we discuss how we empirically test the hypotheses. The model estimates are presented in Section 6. Finally, we summarize and draw some conclusions.

\section{Region-level Determinants of FDI: Descriptive Analysis of the Characteristics of FDI Host Regions}

To be able to formulate clear hypotheses at the micro level about the characteristics of the FDI activities located in different host regions, we first have to characterize the different FDI host regions relative to each other and relative to Switzerland, the home country of the firms, based on a descriptive analysis of five standard determinants of FDI at country or region level as used in gravity models (see, e.g., NaCHUm et al., 2008): level and growth rate of purchasing power, transportation and communication costs, wage costs, innovative potential, and investment costs (see Table 1 for exact definition of used indicators). ${ }^{4}$

We distinguish five main regions (EU15/EFTA, North America, Latin America, Eastern Europe and Asia) that are characterized by using a set of region-level indicators. ${ }^{5}$ The values of these measures, however, are not calculated for the

4 This is not an exhaustive list of potential region-level drivers of FDI activities (e.g., exchange rate, tax differentials, and trade protection are missing). We have focused on more structural characteristics that do not change much. For example, exchange rates and tax differences that fluctuate stronger than other economic factors such as purchasing power and transportation and communication costs are not taken into consideration in Table 1. However, as we focus in this study on differences at firm-level characteristics, we cannot go into more detail.

5 The available micro-level data used in the econometric analysis allows to distinguish nine different host regions of FDI, i.e. EU15/EFTA, Eastern Europe, Southeast Europe, Russia, North 
main regions themselves but only for each region's three most important countries selected according to their share in the Swiss outward FDI capital stock. ${ }^{6}$ This procedure yields a representative picture of the characteristics of the five main regions as it also shows the heterogeneity in terms of the underlying characteristics within the same main region. The values of the relevant indicators for the selected countries representing each main region are shown in Table 1.

The attractiveness of a region as sales market is measured by the level and the growth rate of the purchasing power (level: measured by "GNI per capita, PPP" and "household final consumption per capita"; growth: measured by "5-year GDP per capita" and "household final consumption per capita growth rate") capturing the present and future demand potential. It is highest in EU15/EFTA and North America and lowest in Asia (with the exception of Singapore whose purchasing power is more or less the same as that of the Western countries). Furthermore, we note that some countries of Eastern Europe and Asia could significantly reduce the gap over the last few years.

Wage costs (measured by "gross hourly pay in a big city" and "annual gross employment income per worker") are relevant primarily for firms with labor intensive production processes. Compared to Western countries, these costs are much lower in Asia, Latin America and Eastern Europe. But there are also substantial differences within these low-wage regions; for example, in Mexico as well as in Indonesia and China wages are much lower than in the other countries of the respective main regions.

America, Latin America, China, Asian Tigers and Southeast Asia/India (EU15/EFTA: Austria, Belgium, Britain, Denmark, Finland, France, Germany, Greece, Iceland, Ireland, Italy, Liechtenstein, Luxembourg, the Netherlands, Norway, Portugal, Spain and Sweden; Eastern Europe: Baltic countries, Czech Republic, Hungary, Poland, Slovakia and Slovenia; Southeast Europe: Albania, Bosnia, Bulgaria, Croatia, Macedonia, Montenegro, Romania and Serbia; Russia: Belarus, Russia, and Ukraine; North America: Canada and the USA; Asian Tigers: Hong Kong, Korea, Singapore and Taiwan; Southeast Asia/India: India, Indonesia, Malaysia, Philippine and Thailand). Due to econometric reasons (see Section 5.2) we grouped them into five "main regions", provided that they are not too distant from each other and show similar characteristics (selected according to their relevance in the present context). In order to test the robustness of this aggregation econometrically, we will also present estimations for the sub-categories of the aggregated main regions. The main regions "Eastern Europe" is made up of Eastern Europe (in the narrow sense), Southeast Europe and Russia, and "Asia" comprises China, Asian Tigers and Southeast Asia/India.

6 Germany, Britain and France for EU/EFTA; Poland, Russia and the Czech Republic for Eastern Europe; Brazil, Mexico and Venezuela for Latin America; Singapore, China and Indonesia for Asia; and, finally, Canada and USA for North America. 
The innovative potential of a region is another factor attracting FDI (knowledge sourcing). In order to capture the countries' innovative potential, we use three indicators reflecting a country's share of the labor force with tertiary level education, a country's research and development expenditures, and the number of a country's researchers per million inhabitants, respectively. According to these indicators, the innovative potential is highest in EU15/EFTA and North America.

Moreover, the choice of host regions of FDI is determined by its distance. According to the gravity model of international trade and investment (see, e.g., BraINARD, 1997) long distance between two countries reduces the attractiveness of FDI compared to exporting, since the costs of coordination and control of foreign affiliates are higher in case of distant locations. On the other hand high transport and communication costs (measured by the "bilateral distances between capital cities") are an obstacle to serving these markets by exporting and are thus an incentive for FDI. The net effect of the two opposite forces, which may differ by type of FDI (see below), will be revealed by the empirical analysis. According to Table 1, distances between Switzerland and the most important countries of the region EU15/EFTA are shorter than those to the countries of Eastern Europe. In addition, North America is closer to Switzerland than Latin American and Asian countries.

Investment costs (measured by the "ease of doing business index", the "corruption perceptions index" and the inflation of consumer prices) considerably differ among the selected countries of the five regions. They are much lower in Western countries than in all other regions, once again, with the exception of Singapore which, in this respect, is quite similar to EU/EFTA and North America. In contrast, investment costs are much higher in Brazil, Indonesia, Russia and Venezuela.

The characterization of the five regions in Table 1 serves as conceptual help for formulating now hypotheses about the characteristics of FDI located in the different host regions. 
Table 1: Region-Level Determinants of FDI: Characteristics of the Regions

\begin{tabular}{|c|c|c|c|c|c|c|c|c|c|}
\hline \multirow[b]{2}{*}{ Indicator } & \multicolumn{3}{|c|}{ EU15/EFTA } & \multicolumn{3}{|c|}{ Eastern Europe } & \multicolumn{3}{|c|}{ Latin America } \\
\hline & GER & GBR & FRA & POL & RUS & CZE & BRA & MEX & VEN \\
\hline \multicolumn{10}{|l|}{ Intensity of FDI activities } \\
\hline Share of capital stock of Swiss FDI abroad & 6.9 & 6.3 & 4.4 & 0.6 & 0.7 & 0.4 & 4.1 & 0.7 & 0.2 \\
\hline \multicolumn{10}{|l|}{ Purchasing power } \\
\hline GNI per capita, PPP (current international \$) & 35950 & 36240 & 33280 & 16710 & 15460 & 22890 & 10080 & 14340 & 12850 \\
\hline $\begin{array}{l}\text { Household final consumption expenditure per capita } \\
\text { (constant } 2000 \text { US\$) }\end{array}$ & 13926 & 19400 & 13761 & 3801 & 1877 & 3811 & 2904 & 4762 & 4096 \\
\hline \multicolumn{10}{|l|}{ Growth of purchasing power } \\
\hline 5-year GDP per capita growth (\% 2003-2008; constant 2000 US\$) & 9.5 & 8.5 & 5.9 & 30.1 & 42.8 & 26.3 & 19.1 & 12.2 & 50.4 \\
\hline $\begin{array}{l}\text { Household final consumption expenditure per capita growth } \\
\text { (annual \%) }\end{array}$ & 0.1 & 1.4 & 1.0 & 5.4 & 11.4 & 3.6 & 7.8 & 1.3 & 7.1 \\
\hline \multicolumn{10}{|l|}{ Wage costs } \\
\hline Gross hourly pay in a big city (current US\$/hour) & 23.0 & 18.0 & 18.0 & 5.6 & 6.9 & 6.5 & 5.6 & 2.1 & 5.2 \\
\hline Annual gross employment income per worker (current US\$) & 36444 & 34854 & & & 11378 & 13020 & 9801 & 6143 & \\
\hline \multicolumn{10}{|l|}{ Innovative potential } \\
\hline Labor force with tertiary education ( $\%$ of total) & 24 & 32 & 29 & 22 & 53 & 14 & 9 & 17 & - \\
\hline Research and development expenditures ( $\%$ of GDP) & 2.6 & 1.8 & 2.1 & 0.6 & 1.1 & 1.6 & 1.0 & 0.5 & - \\
\hline Researchers in $\mathrm{R} \& \mathrm{D}$ (per million people) & 3453 & 2881 & 3440 & 1610 & 3305 & 2715 & 629 & 460 & - \\
\hline
\end{tabular}




\begin{tabular}{|c|c|c|c|c|c|c|c|c|c|}
\hline \multirow[b]{2}{*}{ Indicator } & \multicolumn{3}{|c|}{ EU15/EFTA } & \multicolumn{3}{|c|}{ Eastern Europe } & \multicolumn{3}{|c|}{ Latin America } \\
\hline & GER & GBR & FRA & POL & RUS & CZE & BRA & MEX & VEN \\
\hline \multicolumn{10}{|l|}{ Transportation and communication costs } \\
\hline $\begin{array}{l}\text { Bilateral distances between capital cities ( } \mathrm{CH} \text { vs. respective country } \\
\text { in kilometers) }\end{array}$ & 504 & 749 & 436 & 1140 & 2296 & 623 & 9534 & 9640 & 7973 \\
\hline \multicolumn{10}{|l|}{ Investment costs } \\
\hline Ease of doing business index ( $1=$ most business-friendly regulations) & 27 & 6 & 31 & 72 & 118 & 66 & 127 & 55 & 178 \\
\hline Corruption Perceptions Index ( $1=$ highest (perceived) corruption) & 7.9 & 7.7 & 6.9 & 4.6 & 2.1 & 5.2 & 3.5 & 3.6 & 1.9 \\
\hline Inflation of consumer prices (annual \%) & 2.6 & 4.0 & 2.8 & 4.3 & 14.1 & 6.4 & 5.7 & 5.1 & 31.4 \\
\hline
\end{tabular}

Table 1 continued

\begin{tabular}{|c|c|c|c|c|c|c|}
\hline \multirow[b]{2}{*}{ Indicator } & \multicolumn{3}{|c|}{ Asia } & \multicolumn{2}{|c|}{ North America } & \multirow{2}{*}{$\begin{array}{l}\mathrm{CH} \\
\mathrm{CH}\end{array}$} \\
\hline & SGP & $\mathrm{CHN}$ & IND & CAN & USA & \\
\hline \multicolumn{7}{|l|}{ Intensity of FDI activities } \\
\hline Share of capital stock of Swiss FDI abroad & 1.0 & 0.8 & 0.7 & 4.0 & 18.5 & \\
\hline \multicolumn{7}{|l|}{ Purchasing power } \\
\hline GNI per capita, PPP (current international \$) & 47970 & 6010 & 3600 & 38710 & 46790 & 39210 \\
\hline Household final consumption expenditure per capita (constant 2000 US\$) & 9725 & 727 & 622 & 15503 & 27378 & 21950 \\
\hline \multicolumn{7}{|l|}{ Growth of purchasing power } \\
\hline 5-year GDP per capita growth (\% 2003-2008; constant 2000 US\$) & 18.1 & 62.5 & 24.1 & 7.3 & 7.3 & 9.7 \\
\hline Household final consumption expenditure per capita growth (annual \%) & & 8.2 & 5.3 & 4.5 & 2.7 & 2.1 \\
\hline
\end{tabular}




\begin{tabular}{|c|c|c|c|c|c|c|}
\hline \multirow[b]{2}{*}{ Indicator } & \multicolumn{3}{|c|}{ Asia } & \multicolumn{2}{|c|}{ North America } & \multirow{2}{*}{$\begin{array}{l}\mathrm{CH} \\
\mathrm{CH}\end{array}$} \\
\hline & SGP & $\mathrm{CHN}$ & IND & CAN & USA & \\
\hline \multicolumn{7}{|l|}{ Wage costs } \\
\hline Gross hourly pay in a big city (current US\$/hour) & 7.1 & 3.9 & 1.6 & 17.1 & 26.1 & 30.3 \\
\hline Annual gross employment income per worker (current US\$) & 23972 & 4397 & & & 42028 & 35307 \\
\hline \multicolumn{7}{|l|}{ Innovative potential } \\
\hline Labor force with tertiary education ( $\%$ of total) & 24 & - & 7 & 46 & 61 & 30 \\
\hline Research and development expenditures (\% of GDP) & 2.6 & 1.5 & 0.0 & 2.0 & 2.7 & 2.9 \\
\hline Researchers in R\&D (per million people) & 6088 & 1071 & 205 & 4157 & 4663 & 3436 \\
\hline \multicolumn{7}{|l|}{ Transportation and communication costs } \\
\hline $\begin{array}{l}\text { Bilateral distances between capital cities ( } \mathrm{CH} \text { vs. respective country } \\
\text { in kilometers) }\end{array}$ & 10399 & 8084 & 11223 & 6441 & 6272 & \\
\hline \multicolumn{7}{|l|}{ Investment costs } \\
\hline Ease of doing business index ( $1=$ most business-friendly regulations) & 1 & 86 & 129 & 8 & 4 & 19 \\
\hline Corruption Perceptions Index ( 1 =highest (perceived) corruption) & 9.2 & 3.6 & 2.6 & 8.7 & 7.3 & 9.0 \\
\hline Inflation of consumer prices (annual \%) & 6.5 & 5.9 & 10.1 & 2.4 & 3.8 & 2.4 \\
\hline \multicolumn{7}{|c|}{$\begin{array}{l}\text { Notes: Country abbreviations are defined as follows: Germany (GER), United Kingdom (GBR), France (FRA), Poland (POL), Russian Federation } \\
\text { (RUS), Czech Republic (CZE), Brazil (BRA), Mexico (MEX), Venezuela (VEN), Singapore (SGP), China (CHN), Indonesia (IND), Canada (CAN) } \\
\text { United States (USA) and Switzerland (CH). To ensure a high degree of comparability with the data of our survey, the year } 2008 \text { was chosen as basi } \\
\text { for this information. In case of missing data for 2008, the latest available information was used (but no data is provided if it does not refer to a year } \\
\text { later than 2000). Most of the data comes from the Worldbank (WorLDBANk 2010). Exceptions are the variables "Share of capital stock of Swiss FD) } \\
\text { abroad" (SNB 2010), "Gross hourly pay in a big city" (UBS 2009), "Annual employment income per worker" (WorLD SALARIEs 2005), "Bilatera } \\
\text { distances between capital cities" (CEPII 2010) and "Corruption Perceptions Index" (TRANSPARENCY INTERNATIONAL 2008). }\end{array}$} \\
\hline
\end{tabular}




\section{Micro-Level Determinants of FDI and Host Region Characteristics}

The characterization of the different host regions now is used in order to formulate hypotheses on how the firm-level characteristics may vary for firms with FDI activities in the different host regions. In accordance with the few studies dealing with the characteristics of FDI by host regions (Aw and LeE, 2008; Davidson, 1980; Makino et al., 2004; Shatz and Venables, 2000), we formulate a model that contains variables for several characteristics of the parent company in Switzerland and the relationship with its foreign affiliates. Overall the characterization of the FDI activities is based on three categories representing (a) the type of FDI (vertical, horizontal, distribution-oriented), (b) the relevance of FDI experience, and (c) the importance of the firm's capacity to innovate. The results from model estimation (see Section 6) will be interpreted in the light of the hypotheses presented in this section.

\section{Types of FDI}

According to the literature, apart from knowledge sourcing, there are two main reasons why a firm may engage in FDI, namely: (a) to better serve a local market and (b) to get access to low-cost inputs in order to improve competitiveness on local and international markets (Shatz and Venables, 2000). Case (a) is called "horizontal FDI", as firms typically more or less duplicate the same activities in additional plants to supply different locations. In contrast, case (b) referred to as "vertical FDI", implies that the supply chain is fragmented and some parts of it are relocated abroad in order to minimize costs.

If only firms with foreign production facilities are considered, the distinction between horizontal and vertical FDI suffices to cover the entire range of strategies among which MNEs may choose. However, one observes that many MNEs deploy abroad exclusively distribution facilities. Therefore, in the general case, firms have to decide not only between vertical and horizontal production-oriented FDI, but also between "production-oriented" and "distribution-oriented" FDI (for this distinction see Hanson et al., 2001). We thus distinguish the following types of FDI: (a) distribution-oriented FDI, (b) vertical (production-oriented) FDI and (c) horizontal (production-oriented) FDI.

Vertical FDI are expected to be deployed primarily in low-cost countries (see e.g. Blonigen and Wang, 2005). As shown in Table 1, production costs - in particular wage costs - are at lowest in Eastern Europe, Latin America and Asia. In contrast, investment costs are relatively high in these regions. It is an empirical 
question whether the advantage of low labor costs outweighs the disadvantage of high investment costs. We expect that, on balance, production cost advantages dominate in case of the three aforementioned regions. Accordingly, we expect them to attract primarily vertical FDI.

Horizontal FDI are associated with higher fixed costs and might thus be most common in host countries with large markets. The same is true for distributionoriented FDI. However, the incentive for a firm to engage in distribution-oriented rather than horizontal FDI is lower if trade barriers of the host country are high. Transportation costs are another relevant factor (see, e.g., HatTARI and RajAN, 2009 or Mody et al., 2003). As they can be reduced by horizontal FDI, the distance between host and home country is expected to be positively correlated with the cost savings resulting from horizontal FDI compared with the distance-related cost savings in case of distribution-oriented FDI (see Hanson et al., 2001 for a similar reasoning). ${ }^{7}$ EU15/EFTA and North America are the largest (potential) markets and thus particularly attractive for horizontal FDI. However, given the lower trade barriers and shorter distance in case of EU15/ EFTA, the likelihood of Swiss firms to be engaged in distribution-oriented FDI is expected to be higher in EU15/EFTA than in North America. ${ }^{8}$ The above discussion on the three types of FDI implies:

H1: North America, in the first place, attracts horizontal FDI, whereas in case of EU15/EFTA distribution-oriented FDI is predominant. Vertical FDI are hosted primarily by Eastern Europe, Latin America and Asia.

\section{FDI Experience}

The stages view of foreign activities of firms conceptualizes internationalization as a sequential process, with firms exporting their products to foreign markets as the first step. It is only later on that they seek local presence through equity-based activities. At an early stage, MNEs tend to select a host country that is similar to their home country. This preference may gradually change as firms gain experience in international activities. This experience enables firms to expand their activity radius and to invest in more than one country as well as in countries that

7 Cultural distance between domestic and foreign locations may have a similar effect: cost savings in case of production-oriented FDI are higher than those that can be realized by distribution-oriented FDI.

8 The distance-related cost savings in case of production-oriented FDI relative to those of distribution-oriented FDI are particularly high for FDI in knowledge-intensive industries (see Keller and Yeaple, 2009), whose share in Swiss exports and FDI is very high. 
are not similar to the home country (see, e.g., Johanson and Vahlne, 1977; Johanson and Wiedersheim-Paul, 1975). Empirical evidence for the crucial role of foreign experience is found, for example, in Davidson (1980), and more recently in GAZANIOL (2014). We thus formulate the following hypotheses:

H2a: The likelihood that a firm currently has FDI activities in a certain region is particularly high if it has long-standing FDI experience.

$\mathrm{H} 2 \mathrm{~b}$ : Early FDI experience increases the probability that a firm invests in regions whose characteristics are dissimilar to those of Switzerland (primarily Eastern Europe, Latin America, and Asia). Accordingly, the effect of FDI experience on the likelihood of FDI is larger for such dissimilar regions, if we compare the experience effects across regions.

\section{Capabilities for Innovation}

In addition to demand- and cost-related factors, knowledge acquisition is a further important factor that drives FDI. Innovativeness is an important firm-specific characteristic that determines, among other things, the firms' propensity to invest in foreign locations ("ownership advantage"; see, e.g., Dunning, 2000). In addition, innovative firms especially from small countries are likely to seek abroad for additional or complementary know-how (see, among many others, Le BAS and Sierra, 2002), since its domestic knowledge base is mostly limited and/or highly specialized. Hence, we expect that the most advanced countries with high potential for innovation would be particularly attractive locations for "knowledge-seeking FDI" (see Blonigen, 2005; Kogut and Chang, 1991).

As a consequence, we postulate the following hypothesis:

H3a: The likelihood that a firm currently has FDI activities in a certain region is larger for firms with innovation activities at home than for those without such activities.

The low production costs of less developed countries primarily attract less innovative firms. Knowledge seeking in combination with innovation-based O-advantages should thus lead to a higher share of innovative firms with FDI activities in developed than in less developed host regions. The respective hypothesis is as follows:

$\mathrm{H} 3 \mathrm{~b}$ : Innovative firms are more prone to locate FDI in regions with a favorable innovation environment (e.g., many innovative firms; presence of top-level universities) such as North America and EU15/EFTA. We thus expect that the innovation effect is at largest for these regions. 


\section{Data}

The firm data used in this investigation have been collected in the course of a postal survey on the "Internationalization of the Swiss Economy" carried out in spring 2010. The questionnaire has been addressed to a sample of about 4500 firms (with at least five employees) covering the business sector (i.e. including services) of the Swiss economy and is stratified by 29 industries and three industry-specific firm size classes (with full coverage of large companies). The survey yielded valid information for 1921 enterprises, implying a response rate of $42 \%$, what is satisfactory given the very demanding questionnaire. Due to selective reminding calls among firms that were underrepresented in a first round of data collection, the final structure of the responding firms in terms of size and industry affiliation is quite similar to that of the underlying sample. 545 firms are engaged in FDI (about $28 \%$ of all valid responses). A non-response analysis indicated that this share is representative for the whole sample. Depending on the number of missing values of the explanatory variables that differs considerably across the estimated models (see below) 334 to 473 observations could be used to analyze econometrically the characteristics of the FDI firms.

On average the MNEs in our sample (i.e., the firms with FDI activities) have 814 employees, whereupon the distribution is strongly right-skewed. $51 \%$ of the firms have between 50 and 250 employees and only $22 \%$ employ more than 250 employees.

$72 \%$ of the firms belong to the manufacturing sector, $26 \%$ to the service sector and only $2 \%$ to the construction sector. In the service sector the sub-sector of modern (knowledge-intensive) services (e.g., banking and insurance, business services) has a larger share than the sub-sector of traditional services (e.g., trade, hotels and catering) (53\% vs. $47 \%)$. In the manufacturing sector there are more high-tech than low-tech firms (66\% vs. $34 \%$ ).

The available data are to a high extent qualitative in nature (nominal or ordinal measures). The survey yielded information on international activities differentiated by type (e.g., exports, licensing, as well as FDI related to distribution, production, R\&D), degree of ownership control (e.g., wholly-owned affiliate, joint ventures), regional orientation of FDI, motives for and obstacles to FDI, and type and extent of the (two-way) trade flows between parent companies and their foreign subsidiaries. Firms that reported the existence of (only) production plants for final products or services (full ownership or joint venture) in foreign locations belong to the group of firms with "horizontal production-oriented" FDI; firms that reported that they have affiliates for production of final products or services and intermediate products or services and/or R\&D activities (fully-owned or joint 
ventures) in countries other than Switzerland belong to the firms with "vertical FDI". Finally, firms reporting only distribution activities abroad build the group of forms with "distribution-oriented" FDI. In addition, we collected information about innovative activities and some basic characteristics of the firm (e.g., sales, value added, employment, firm age, industry affiliation). ${ }^{9}$ For descriptive information on the model variables based on the respective estimation samples see Table A.1 in the appendix. The correlation matrix is presented in Table A.2.

\section{Empirical Test of Hypotheses}

\subsection{Operationalization of Hypotheses}

As made clear in the beginning, the goal of this study is to analyze how the characteristics of firms differ at time of observation, depending on where they have located their FDI activities at this point in time. Hence, we are not interested in identifying determinants of starting FDI activities in a certain region, but simply compare the characteristics of firms that have FDI activities in a certain region with firms that have FDI activities in other regions.

Hypothesis 1 focuses on the differentiation between vertical (production-oriented) FDI, horizontal (production-oriented) FDI and distribution-oriented FDI (see also Section 4). Hypothesis 1 is tested using three different types of indicators. A first variable measures the change of the parent firms' employment in Switzerland in the upswing period 2003-2008. Since vertical FDI involves the relocation of parts of the supply chain, this type of FDI implies as a direct effect a reduction of the domestic employment of the parent company. ${ }^{10}$ Therefore, in line with H1, we expect that parent firms having invested in Eastern Europe, Latin America and Asia, respectively, recorded a decrease of employment or a weaker growth of employment in the reference period than those with FDI in other regions. Of course there can be also other reasons for a reduction of domestic employment, the most important of them being the general level of domestic economic conditions.

9 The questionnaire is available in German, French and Italian on www.kof.ethz.ch/en/surveys/ structural-surveys/other-surveys/survey-internationalisation-swiss-economy-2010/.

10 In the longer run, the relocation of certain parts of the supply chain abroad may also improve the competitiveness of a firm, leading to an increase of jobs in Switzerland (indirect effect) (see Grossman and Rossi-Hansberg, 2008 for this argument). However, we presume that, on balance, the negative employment effect weighs more. 
A second measure we use to represent the three types of FDI is based on the intensity of the two-way trade flows of goods/services between the parent company and its foreign subsidiaries (intra-firm trade flows). As distribution-oriented FDI are associated with large outflows of products to the foreign sales market, we expect considerable net outflows to regions where this type of FDI is predominant. On the other hand, we should observe net inflows from regions that primarily are destinations of vertical FDI (intra-firm deliveries of primary and intermediate products to the parent company). In case of horizontal FDI, we expect neither substantial outflows nor inflows since production takes place locally. Accordingly, trade inflows from regions hosting horizontal FDI should be smaller than outflows to countries having received vertical FDI. Finally, we expect that outflows to host regions of horizontal FDI are smaller than outflows to locations having attracted predominantly distribution-oriented FDI.

The third measure focuses on production-oriented FDI. Based on the sub-sample of firms engaged in this type of FDI, we analyze the probability of a firm locating its production facilities in a certain region. Data on the firms' motives for establishing (or extending) production sites in foreign locations allow us to distinguish between "cost-related" and "market-related" motives. Examples of the latter are "market expansion", "early market presence to gain a competitive advantage" or "following customers by establishing production facilities abroad". Cost-oriented motives are, for example, "lower labor costs", "more flexible labor market regulations", "tax advantages" or "less strict environmental laws" in host regions as compared with Switzerland. We expect that horizontal FDI are driven by market-related motives, whereas cost-oriented motives dominate in regions hosting vertical FDI.

Hypothesis 2 emphasizes the impact of FDI experience. Our dataset contains information on the period of the first-time FDI activity and the age of firms. First-time presence is used as a direct measure of FDI experience, whereas firm age indirectly captures FDI experience as it is expected to correlate positively with industry and export experience.

Hypothesis 3 refers to a firm's innovation activities. In line with previous literature (see Kogut and CHANG, 1991) the innovation potential of an MNE is captured by variables measuring the domestic innovation intensity of the parent company. Innovation intensity is captured by (a) the share of $R \& D$ activities in total sales (R\&D intensity) and (b) the share of employees with a tertiary-level degree (human capital intensity). 
Table 2: Variable Definition and Measurement

\begin{tabular}{|c|c|c|}
\hline & Variable & Definition / measurement \\
\hline \multirow{3}{*}{ 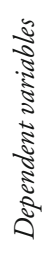 } & $\begin{array}{l}\text { EU15/EFTA; Eastern Europe; North } \\
\text { America; Latin America; Asia }\end{array}$ & $\begin{array}{l}\text { The firm has foreign affiliates in a certain "main" } \\
\text { region (yes/no) }\end{array}$ \\
\hline & $\begin{array}{l}\text { Eastern Europe; Southeast Europe; } \\
\text { Russia }\end{array}$ & $\begin{array}{l}\text { The firm has foreign affiliates in a certain "sub- } \\
\text { region" of Eastern Europe (yes/no) }\end{array}$ \\
\hline & $\begin{array}{l}\text { China; Asian Tigers; Southeast Asia/ } \\
\text { India }\end{array}$ & $\begin{array}{l}\text { The firm has foreign affiliates in a certain "sub- } \\
\text { region" of Asia (yes/no) }\end{array}$ \\
\hline \multirow{11}{*}{ 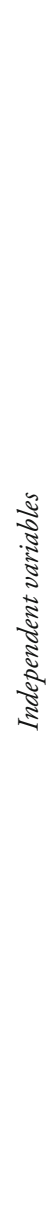 } & first_fdi_1990 & $\begin{array}{l}\text { The firm already had FDI activities before } 1990 \\
\text { (yes/no) } \\
\text { (reference group: firms that started FDI activities } \\
\text { after 2000) }\end{array}$ \\
\hline & first_fdi_2000 & $\begin{array}{l}\text { The firm started FDI activities between } 1990 \text { and } \\
2000 \text { (yes/no) } \\
\text { (reference group: firms that started FDI activities } \\
\text { after 2000) }\end{array}$ \\
\hline & firm_age & Number of years natural logarithm \\
\hline & r\&d_intensity & $\begin{array}{l}\text { Sales share of } \mathrm{R} \& \mathrm{D} \text { expenditures; natural } \\
\text { logarithm }\end{array}$ \\
\hline & tertiary_share & $\begin{array}{l}\text { Share of employees with a tertiary-level degree; } \\
\text { natural logarithm }\end{array}$ \\
\hline & employment_growth & $\begin{array}{l}\text { Change of the natural logarithm of the number of } \\
\text { employees between } 2003 \text { and } 2008\end{array}$ \\
\hline & inflow & $\begin{array}{l}\text { Share of goods/services that the Swiss parent } \\
\text { company imported from foreign subsidiaries } \\
\text { (nine-level variable: } 0 \%, 1-5 \%, 6-10 \%, 11-15 \% \text {, } \\
16-20 \%, 21-30 \%, 31-40 \%, 41-50 \% \text { and } \\
51-100 \% \text { ) }\end{array}$ \\
\hline & outflow & $\begin{array}{l}\text { Share of goods/services that the Swiss parent } \\
\text { company exported to foreign subsidiaries } \\
\text { (nine-level variable: } 0 \%, 1-5 \%, 6-10 \%, 11-15 \% \text {, } \\
16-20 \%, 21-30 \%, 31-40 \%, 41-50 \% \text { and } \\
51-100 \% \text { ) }\end{array}$ \\
\hline & $\begin{array}{l}\text { sales_motive; institutional_motive; } \\
\text { production_cost_motive; } \\
\text { input_motive }\end{array}$ & $\begin{array}{l}\text { Factor scores of motives for production-oriented } \\
\text { FDI (see Table A.3 in the appendix) }\end{array}$ \\
\hline & size & Number of employees 2008; natural logarithm \\
\hline & industry & Dummies for the industry affiliation of the firm \\
\hline
\end{tabular}




\subsection{Econometric Framework}

The dependent variable is a dummy variable that takes the value one for MNEs with subsidiaries in a certain region and value zero otherwise (for a detailed definition of all variables see Table 2; the descriptive statistics are shown in Table A.1 in the appendix). Due to the fact that many parent companies invest at the same time in several host regions, it is likely that the decisions on FDI locations are correlated. This was confirmed by LR-tests of the multivariate probit against independent univariate probits for all models we estimated. The residuals of the dependent variables of the different models were thus not independent of each other. To take account of such interdependencies we estimated a multivariate probit model for all nine host regions. As the model did not converge when we included all nine FDI host regions at ones, we chose a two-step approach. In a first step, we estimated a multivariate probit model for the five "main regions" as defined in Section 2.1 (EU/EFTA, North America, Latin America, Eastern Europe, and Asia). In a second step, we captured, where necessary, differences between sub-regions by estimating a multivariate probit model separately for the three sub-regions of the main regions "Eastern Europe" ("Eastern Europe" in the narrow sense, "Southeast Europe" and "Russia") and "Asia" ("China", "Asian Tigers" and "Southeast Asia/India").

As some of the model variables are not available for firms without FDI, we had to restrict the estimation sample to firms having invested abroad. As a consequence, we assumed that a firm's location choice is taken independently of its general FDI decision. Therefore, focusing on FDI performing firms should not affect the estimation results. Nevertheless we tested for a potential selection bias. By applying the Stata heckprob procedure, we separately tested for each of the five "main regions" whether the firms' general FDI decision does affect its location choice. ${ }^{11}$ As the LR tests of independent equations were statistically insignificant

11 The selection equation of the Heckman model is specified in the same way as the outcome equation, with the exception of the additional identifying variable that is not in the outcome equation. To identify the Heckman model, instrument variables are added to the selection equations. The instruments are industry averages of variables that measure the firms' demand development (average of two 5-level ordinal variables that measure the firm's expected and past demand development, respectively; in the estimates explaining FDI activities in the USA only information on the firms' expected demand development is used). In order to construct the industry averages we can use the whole data set and are not restricted to firms with FDI activities. Hence the averages are constructed on the NACE 3-digit level, which allows us to additionally include the industry controls (aggregated 2-digit level) in our estimates. We assume that these industry variables pick-up the effect of unobserved industry-specific attributes that contribute to the potential endogenous firm-specific variables (see, e.g., Cassiman 
for each region, there is no evidence for a selection bias, and we conclude that focusing on firms with FDI activities is an adequate procedure.

The analysis, as most studies in this field of research, is based on cross-sectional data (see Section 3). Therefore, the potential problem of endogeneity cannot be solved. As a consequence, one should be cautious in interpreting the results as causal relationships. Hence we refrain from making causal claims, but rather interpret the estimated coefficients as partial correlations. Furthermore, we focus on interpreting the relative size of the correlations across the different regions and refrain from interpreting the size of the single parameters. Hence, we also do not present the marginal effects of the estimates. Nevertheless the results show whether and to what extent the results are in line with the hypotheses postulated in Section 2.3.

\subsection{Specification of Three Empirical Models}

We estimated three different models which share the variables representing FDI experience and innovation input but differ with respect to the variables reflecting the effects of the FDI type (employment growth, intensity of intra-firm trade, motives for "production-oriented" FDI). Model I ("Basic Model”) contains (in addition to FDI experience, innovation input and some general controls) only the variable measuring employment growth in order to be able to exploit the maximum of available data (473 observations). Due to differing numbers of missing values we had to estimate separately Model II (adding the variables for intra-firm trade, thus using only 334 observations) and Model III (using the variables representing the motives for production-oriented FDI instead of the variables capturing intra-firm trade, thus reducing the sample to 371 observations). ${ }^{12}$

and Veugelers, 2002, p. 1174 for a similar justification of the use of industry variables as instruments). Accordingly, it can be assumed that these instruments are uncorrelated with the error term. Furthermore, all instruments are correlated with the dependent variable in the selection equation (FDI yes/no) but uncorrelated with the dependent variable in the outcome equation (location choice). As information on specific FDI characteristics of the firms (e.g., on FDI experience or trade flows) is only available for firms with FDI activities, we could not include these variables in our selection model. The detailed estimation results are available on request.

12 The correlation between employment growth and the flow variables for intra-firm trade is about 0.15 , between employment growth and the motive variables about 0.12 . Thus, there is no issue of multicollinearity if both variables are used in the same model. However, the flow variables and the motive variables (particularly the inflow variable and the production cost motive variable) are strongly correlated. To avoid this multicollinearity problem, the two groups of variables are thus estimated in separate models. 
Model I includes two explanatory variables describing the parent firm's FDI experience (first_fdi; firm_age), two types of innovation input ( $r \mho d \_i n t e n s i t y$, tertiary_share) and the change of domestic employment of the parent firm in the upswing period 2003-2008 (employment_growth). Furthermore, we control for firm size (size) and industry affiliation (industry). A formal expression of Model I for firm $i$ is as follows:

$$
\begin{aligned}
F D I_{, i}= & b_{0}+b_{1} \text { first_fdi }_{i-1} 1990+b_{2} \text { first_fdi }_{i_{-}} 2000+b_{3} \text { firm_age }_{i} \\
& +b_{4} r \delta D_{-} \text {intensity }+b_{5} \text { tertiary_share } \\
& +b_{6} \text { employment_growth }{ }_{i}+b_{7} \text { size }_{i}+\text { industry_controls }+e_{i} .
\end{aligned}
$$

In Model II, we investigated the effect of the intensity of the two-way trade flows between the parent company and its foreign subsidiaries on the selection of FDI host regions. To this end we used the variable inflow measuring the intensity of flows of goods/services from foreign subsidiaries to the parent company in Switzerland, whereas outflow represents the intensity of flows in the opposite direction. Apart from that we inserted the variables contained in Model I. In formal terms is Model II as follows:

$$
\begin{aligned}
F D I_{, i}= & b_{0}+b_{1} \text { first_fdi }_{i-1} 1990+b_{2} \text { first_fdi }_{i-2} 2000+b_{3} \text { firm_age }_{i} \\
& +b_{4} r \mho D_{-} \text {intensity } b_{5}+b_{5} \text { tertiary_share } \\
& +b_{6} \text { employment_growth }{ }_{i}+b_{7} \text { size }_{i}+\mathrm{b}_{8} \text { inflow }+b_{9} \text { outflow } \\
& +{\text { industry_controls }+e_{i} .}
\end{aligned}
$$

Finally, in Model III we analyzed whether the motives for production-oriented FDI differ among regions. The respective data refer to 20 single motives, the importance of which has been assessed by the firms on a five-point Likert scale. Using principal component factor analysis of the single motives, we identified four groups of motives for production-oriented FDI (see Table A.3 in the appendix for detailed information on the individual motives and the factor pattern matrix). Factor 1 stands for sales-oriented motives (sales_motive), whereas the factors 2 to 4 refer to three types of cost-oriented motives: factor 2 captures the institutional conditions in the host regions (institutional_motive) such as less restrictive environmental laws or more flexible labor market regulations as compared with Switzerland. Factor 3 depicts advantages of the host regions with respect to production costs (production_cost_motive); finally, factor 4 represents the host countries' advantages with respect to the availability of certain input factors (input_motive) such as natural resources or labor. The four "motive variables" extracted by factor analysis are added to the explanatory variables used in Model I whereas the specific variables of Model II, i.e. those measuring the intra-firm trade flows (inflow and outflow), were dropped. Formally expressed: 


$$
\begin{aligned}
& \mathrm{FDI}_{, \mathrm{i}}=b_{0}+b_{1} \text { first_fdi } i_{-1} 1990+b_{2} \text { first_fdi } i_{i-} 2000 \\
& +b_{3} \text { firm_age }_{i}+b_{4} r \sigma_{0} D_{\text {intensity }}+b_{5} \text { tertiary_share }{ }_{i} \\
& +b_{6} \text { employment_growth }{ }_{i}+b_{7} \text { size }_{i}+b_{8} \text { sales_motive } \\
& +b_{9} \text { institutional_motive }+b_{10} \text { production_cost_motive } \\
& +b_{11} \text { input_motive }+ \text { industry_controls }+e_{i} \text {. }
\end{aligned}
$$

\section{Estimation Results}

\subsection{Model I: Basic Model}

Results for Model I are presented in Table 3. Columns (1) to (5) show the results for the five main regions. Columns (6) to (8) and (9) to (10), respectively, contain, based on the same model, the findings for the sub-regions of the two aggregated regions. In case of Model I, the estimation results for the sub-regions of Eastern Europe as well as those for Asia are more or less the same as for the corresponding aggregated regions. Therefore, in analyzing the results of Model I, we focus on differences among the five main regions. As we simultaneously estimate the model for the five regions, Wald tests allow us to directly compare the coefficients across the different regions.

\subsubsection{Vertical versus Horizontal FDI}

Results for the variable "employment_growth" (referring to the 1990s) provide some first evidence with respect to hypothesis H1. It turns out that domestic employment growth of firms having FDI at locations in the regions Eastern Europe and Asia is significantly smaller (based on Wald tests) than for companies with FDI in EU15/EFTA and, to a lesser extent, North America. Hence, FDI in the former two regions serve to relocate some parts of the supply chain ("vertical FDI"), what is in line with H1. Surprisingly, employment growth of Swiss parent companies with FDI in Latin America is not significantly smaller than that of firms with FDI in Western countries. This may be due to the fact that the average size of the company group (parent firm and all its affiliates) is much larger in case of firms with FDI in Latin America than for those having invested elsewhere. ${ }^{13}$ Accordingly, it seems plausible that primarily a global presence, and not the relocation of employees, motivates the firms to directly invest in this region.

13 Average employment of the company group with FDI in the EU15/EFTA is 2948, in Eastern Europe 4274, in North America 4865, in Asia 4135 and in Latin America 7039. 


\subsubsection{FDI Experience}

In line with hypothesis $\mathrm{H} 2 \mathrm{a}$, the probability that a firm has FDI activities in a certain region is significantly higher (based on Wald tests) for firms that already had FDI activities before 1990 (first_fdi_1990) than for companies that have invested abroad only after 2000 (within region comparisons). Furthermore, this effect increases with the extent of FDI experience as, for each region, the coefficient of first_fdi_1990 is significantly larger than that of first_fdi_2000.

In contrast, the findings referring to the differences across regions, taken as a whole are not consistent with hypothesis H2b. The coefficients of first_fdi_1990 and first_fdi_2000 estimated for EU15/EFTA, North America and Asia are significantly larger than those we found for Eastern Europe and Latin America (confirmed by Wald tests on the equality of coefficients across region-specific equations). Contrary to our hypothesis, less experienced firms have a higher probability to invest in the more dissimilar regions Eastern Europe and Latin America than in the more similar regions EU15/EFTA and North America. Accordingly, FDI experience seems to affect primarily the extent of coverage of FDI host regions (number of regions where a firm is present) rather than the choice of a specific FDI location itself.

The coefficients of firm age (firm_age), our second measure of FDI experience, are insignificant for all target regions. Industry and export experience that are associated with this variable do not seem to affect the choice of locations of FDI.

\subsubsection{Capabilities for Innovation}

In most regions, highly innovative parent firms (measured by rêd_intensity and tertiary_share) are more likely to invest than non-innovative firms, what is in line with hypothesis $\mathrm{H} 3 \mathrm{a}$. In less developed regions this is the case because of $\mathrm{O}$-advantages of the parent firms; in North America, among other things, because of its attractiveness for knowledge-seeking FDI. In contrast to $\mathrm{H} 3 \mathrm{a}$, innovative parent firms do not invest more often in EU15/EFTA than other firms.

Hypothesis $\mathrm{H} 3 \mathrm{~b}$ is only partly confirmed by the estimates. As expected, the coefficients of the two innovation input variables ( $r \& d$ \& intensity, tertiary_share) are larger for North America than those for the less developed region Eastern Europe. However, contrary to our expectations, this is not the case for the regions Latin America and Asia and, again in contrast to H3b, the innovation potential of firms has a significantly smaller impact on the likelihood of FDI in EU15/ EFTA. Overall, the evidence for $\mathrm{H} 3 \mathrm{~b}$ is quite weak.

As these results are surprising, we looked at the matter in some more detail by way of a descriptive analysis of domestic and foreign R\&D activities of Swiss 
Table 3: Firm Characteristics by FDI Host Regions; Model I (Basic Model); Multivariate Probit Estimates

\begin{tabular}{|c|c|c|c|c|c|c|c|c|c|c|c|}
\hline & \multicolumn{5}{|c|}{ All regions } & \multicolumn{3}{|c|}{ Eastern Europe } & \multicolumn{3}{|c|}{ Asia } \\
\hline & $\begin{array}{l}\text { EU15/ } \\
\text { EFTA }\end{array}$ & $\begin{array}{l}\text { Eastern } \\
\text { Europe }\end{array}$ & $\begin{array}{c}\text { North } \\
\text { America }\end{array}$ & $\begin{array}{c}\text { Latin } \\
\text { America }\end{array}$ & Asia & $\begin{array}{l}\text { Eastern } \\
\text { Europe }\end{array}$ & $\begin{array}{c}\text { SE } \\
\text { Europe }\end{array}$ & Russia & China & $\begin{array}{l}\text { Asian } \\
\text { Tigers }\end{array}$ & $\begin{array}{l}\text { SE Asia/ } \\
\text { India }\end{array}$ \\
\hline _cons & $\begin{array}{c}0.219 \\
(0.669)\end{array}$ & $\begin{array}{c}-0.775 \\
(0.497)\end{array}$ & $\begin{array}{l}-2.962^{* * *} \\
(0.629)\end{array}$ & $\begin{array}{l}-2.695^{* * *} \\
(0.636)\end{array}$ & $\begin{array}{c}-2.727^{* * *} \\
(0.588)\end{array}$ & $\begin{array}{l}-0.995^{* *} \\
(0.493)\end{array}$ & $\begin{array}{c}-1.053^{* *} \\
(0.529)\end{array}$ & $\begin{array}{l}-2.717^{* * *} \\
(0.620)\end{array}$ & $\begin{array}{l}-3.145^{* * *} \\
(0.620)\end{array}$ & $\begin{array}{l}-2.600^{* * *} \\
(0.617)\end{array}$ & $\begin{array}{c}-2.076^{* * *} \\
(0.596)\end{array}$ \\
\hline first_fdi_1990 & $\begin{array}{l}1.066^{* * *} \\
(0.226)\end{array}$ & $\begin{array}{l}0.681^{* * *} \\
(0.184)\end{array}$ & $\begin{array}{l}1.174^{* * *} \\
(0.231)\end{array}$ & $\begin{array}{l}0.458^{* *} \\
(0.211)\end{array}$ & $\begin{array}{l}0.914^{* * *} \\
(0.193)\end{array}$ & $\begin{array}{l}0.649^{* * *} \\
(0.187)\end{array}$ & $\begin{array}{l}0.664^{* * *} \\
(0.208)\end{array}$ & $\begin{array}{l}0.961^{* * *} \\
(0.242)\end{array}$ & $\begin{array}{l}0.860^{* * *} \\
(0.221)\end{array}$ & $\begin{array}{l}1.049^{* * *} \\
(0.238)\end{array}$ & $\begin{array}{l}0.781^{\text {*** }} \\
(0.215)\end{array}$ \\
\hline first_fdi_2000 & $\begin{array}{c}0.569^{* *} \\
(0.236)\end{array}$ & $\begin{array}{c}0.153 \\
(0.203)\end{array}$ & $\begin{array}{l}0.907^{* * *} \\
(0.251)\end{array}$ & $\begin{array}{c}0.011 \\
(0.242)\end{array}$ & $\begin{array}{l}0.601^{* * *} \\
(0.212)\end{array}$ & $\begin{array}{c}0.233 \\
(0.211)\end{array}$ & $\begin{array}{c}0.110 \\
(0.238)\end{array}$ & $\begin{array}{c}0.293 \\
(0.272)\end{array}$ & $\begin{array}{l}0.713^{* * *} \\
(0.242)\end{array}$ & $\begin{array}{c}0.628^{* *} \\
(0.259)\end{array}$ & $\begin{array}{c}0.279 \\
(0.241)\end{array}$ \\
\hline firm_age & $\begin{array}{c}-0.024 \\
(0.117)\end{array}$ & $\begin{array}{c}-0.047 \\
(0.087)\end{array}$ & $\begin{array}{c}-0.007 \\
(0.094)\end{array}$ & $\begin{array}{c}-0.109 \\
(0.095)\end{array}$ & $\begin{array}{c}-0.036 \\
(0.089)\end{array}$ & $\begin{array}{c}-0.077 \\
(0.087)\end{array}$ & $\begin{array}{c}-0.120 \\
(0.090)\end{array}$ & $\begin{array}{c}-0.049 \\
(0.095)\end{array}$ & $\begin{array}{c}-0.009 \\
(0.092)\end{array}$ & $\begin{array}{c}-0.042 \\
(0.091)\end{array}$ & $\begin{array}{c}-0.153^{*} \\
(0.093)\end{array}$ \\
\hline r\&d_intensity & $\begin{array}{l}-0.018 \\
(0.036)\end{array}$ & $\begin{array}{l}0.089^{* * *} \\
(0.028)\end{array}$ & $\begin{array}{l}0.113^{* * *} \\
(0.029)\end{array}$ & $\begin{array}{c}0.060^{*} \\
(0.031)\end{array}$ & $\begin{array}{c}0.047^{*} \\
(0.027)\end{array}$ & $\begin{array}{l}0.078^{* * *} \\
(0.028)\end{array}$ & $\begin{array}{l}0.093^{* * *} \\
(0.030)\end{array}$ & $\begin{array}{c}0.069^{* *} \\
(0.032)\end{array}$ & $\begin{array}{c}0.048^{*} \\
(0.029)\end{array}$ & $\begin{array}{c}0.054^{*} \\
(0.029)\end{array}$ & $\begin{array}{c}0.046 \\
(0.029)\end{array}$ \\
\hline tertiary_share & $\begin{array}{l}-0.007 \\
(0.102)\end{array}$ & $\begin{array}{c}-0.108 \\
(0.072)\end{array}$ & $\begin{array}{c}0.220^{* *} \\
(0.100)\end{array}$ & $\begin{array}{l}0.332^{* * *} \\
(0.103)\end{array}$ & $\begin{array}{l}0.349^{* * *} \\
(0.096)\end{array}$ & $\begin{array}{c}-0.068 \\
(0.071)\end{array}$ & $\begin{array}{c}-0.059 \\
(0.079)\end{array}$ & $\begin{array}{c}0.121 \\
(0.100)\end{array}$ & $\begin{array}{l}0.259^{* *} \\
(0.102)\end{array}$ & $\begin{array}{c}0.225^{* *} \\
(0.100)\end{array}$ & $\begin{array}{c}0.164^{*} \\
(0.096)\end{array}$ \\
\hline employment_growth & $\begin{array}{c}0.443^{* *} \\
(0.213)\end{array}$ & $\begin{array}{c}-0.202 \\
(0.172)\end{array}$ & $\begin{array}{c}0.160 \\
(0.181)\end{array}$ & $\begin{array}{c}0.176 \\
(0.182)\end{array}$ & $\begin{array}{c}-0.214 \\
(0.177)\end{array}$ & $\begin{array}{c}-0.128 \\
(0.178)\end{array}$ & $\begin{array}{c}-0.236 \\
(0.184)\end{array}$ & $\begin{array}{c}-0.085 \\
(0.192)\end{array}$ & $\begin{array}{c}-0.014 \\
(0.177)\end{array}$ & $\begin{array}{c}-0.184 \\
(0.171)\end{array}$ & $\begin{array}{c}-0.018 \\
(0.170)\end{array}$ \\
\hline size & $\begin{array}{c}0.130^{*} \\
(0.069)\end{array}$ & $\begin{array}{l}0.172^{* * *} \\
(0.045)\end{array}$ & $\begin{array}{l}0.217^{* * *} \\
(0.048)\end{array}$ & $\begin{array}{c}0.203^{* * *} \\
(0.050)\end{array}$ & $\begin{array}{c}0.193^{* * *} \\
(0.046)\end{array}$ & $\begin{array}{l}0.179^{* * *} \\
(0.046)\end{array}$ & $\begin{array}{l}0.150^{* * *} \\
(0.048)\end{array}$ & $\begin{array}{c}0.234^{* * *} \\
(0.050)\end{array}$ & $\begin{array}{l}0.208^{* * *} \\
(0.047)\end{array}$ & $\begin{array}{l}0.137^{* * *} \\
(0.047)\end{array}$ & $\begin{array}{l}0.216^{* * *} \\
(0.047)\end{array}$ \\
\hline industry & yes & yes & yes & yes & yes & yes & yes & yes & yes & yes & yes \\
\hline $\mathrm{N}$ & & & 473 & & & & 473 & & & 473 & \\
\hline Wald chi ${ }^{2}$ & & & $256.16^{* * *}$ & & & & $103.05^{* * *}$ & & & $137.86^{* * *}$ & \\
\hline $\begin{array}{l}\text { LR test of the multivariate probit } \\
\text { against independent univariate probits }\end{array}$ & & & $281.58^{* * *}$ & & & & $255.14^{* * *}$ & & & $270.59^{* * *}$ & \\
\hline
\end{tabular}

Notes: See Table 2 for the variable definitions; standard errors are in brackets under the coefficients; ${ }^{* * *},{ }^{* *},{ }^{*}$ denote statistical significance at the $1 \%$, $5 \%$ and $10 \%$ test level, respectively. Estimates are based on 100 draws (change in estimates as the number of draws is further increased is negligible). 
firms, differentiating by host regions of FDI. The results are presented in Table 4. The data shown in the first row of the table reveal that the share of R\&D performing parent firms varies across FDI host regions more or less in the same way as the coefficients found for $\mathrm{r} \& \mathrm{~d}$ _intensity in the model estimates (for example, North America high share and statistically significant coefficient, EU15/EFTA low share and insignificant coefficient). In case of EU15/EFTA, not less than $30 \%$ of firms without own R\&D are present with FDI in this region. This is probably due to its relative attractiveness for distribution-oriented FDI (see the estimates for Model II in subsection 6.2) as well as for reasons not explicitly accounted for in the model (e.g. historical ties, geographic and cultural proximity, etc.). These effects seem to be much stronger than that of the high innovation potential of locations in EU15/EFTA.

The second row shows, in line with H3b, that foreign affiliates in EU15/EFTA and North America have much more often local R\&D activities than those present in Latin America and Eastern Europe.

China is the only country that does not fit the pattern observed for the less advanced regions as described in $\mathrm{H} 3 \mathrm{~b}$. There are probably two explanations for this result. Firstly, most FDI in Chinese R\&D centers are concentrated in Beijing and Shanghai that have a well-developed infrastructure, highly qualified human resources and some top-class universities (see GASSMANN and HaN, 2004). Hence the innovation environment of China as a whole is not representative for the economic core regions of this country (what to some extent is also true for India). Besides, the quite impressive R\&D activity of local affiliates may also reflect the policy of Chinese authorities pushing foreign firms to transfer their technology.

Accordingly, it seems that the unexpected results with respect to $\mathrm{H} 3 \mathrm{~b}$ are primarily driven by the low correlation between the firms' propensity to perform $\mathrm{R} \& \mathrm{D}$ at home and to invest abroad in such activities (row 3 of Table 4). The respective correlation coefficient is lower than 0.2 for all regions, with the exception of EU15/EFTA (0.36).

To sum up, the descriptive analysis documented in Table 4 allows us to distinguish three types of regions representing different combinations of domestic and foreign R\&D. Firstly, EU15/EFTA attracts a much higher percentage of Swiss firms that are not active in R\&D. However, as EU15/EFTA denotes a significantly higher correlation between R\&D activities at home and abroad than the other regions, a much higher percentage of R\&D-performing parent companies also invest locally in such activities. Secondly, North America and Asia (for example China) typically host affiliates of R\&D-performing parent firms, a significant percentage of which are active in $\mathrm{R} \& \mathrm{D}$ also locally. Thirdly, in case 
of FDI in Latin America and Eastern Europe (most accentuated in Southeast Europe and Russia) R\&D activities remain primarily located in Switzerland.

Table 4: Descriptive Analysis of R\&D Activities

\begin{tabular}{|c|c|c|c|c|c|c|c|c|c|c|c|}
\hline & \multicolumn{5}{|c|}{ All regions } & \multicolumn{3}{|c|}{ Eastern Europe } & \multicolumn{3}{|c|}{ Asia } \\
\hline & 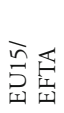 & 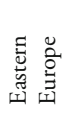 & 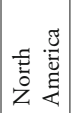 & . & $\frac{\pi}{4}$ & 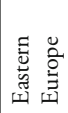 & 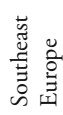 & 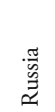 & $\stackrel{\text { : }}{\tilde{U}}$ & 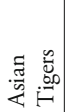 & 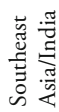 \\
\hline $\begin{array}{l}\text { Percentage share of firms with R\&D } \\
\text { activities in Switzerland by FDI } \\
\text { location }\end{array}$ & 70 & 80 & 87 & 83 & 80 & 80 & 81 & 86 & 82 & 81 & 81 \\
\hline $\begin{array}{l}\text { Percentage share of firms with R\&D } \\
\text { activities in a certain region by FDI } \\
\text { location }\end{array}$ & 29 & 9 & 22 & 4 & 14 & 8 & 3 & 3 & 12 & 8 & 7 \\
\hline $\begin{array}{l}\text { Correlation of } \mathrm{R} \& \mathrm{D} \text { propensity at } \\
\text { home and abroad }\end{array}$ & 0.36 & 0.16 & 0.17 & -0.02 & 0.14 & 0.15 & 0.08 & 0.07 & 0.08 & 0.08 & 0.13 \\
\hline Number of observations & 422 & 238 & 204 & 119 & 244 & 212 & 135 & 126 & 181 & 158 & 158 \\
\hline
\end{tabular}

Source: Survey on the "Internationalization of the Swiss Economy" (see Section 4).

\subsection{Model II: Intra-firm Trade Flows}

Table 5 shows the results for Model II that extends Model I by including the trade flow variables (inflow, outflow) that reveal the role of different types of FDI in more detail. The intensity of trade flows from the foreign affiliates to their parent company in Switzerland (inflow) is significantly larger for firms with FDI in Eastern Europe or Asia (to a lesser extent also in Latin America) than for companies that invested in EU15/EFTA or North America. If we take account only of statistically significant differences of the coefficients of inflow, we get the following pattern:

$($ Eastern Europe $=$ Asia $)>$ Latin America $>(E U 15 / E F T A=$ North America $)$.

On the other hand, the flows from the parent companies to their foreign subsidiaries (outflow) are significantly larger for EU15/EFTA, North America and Eastern Europe, respectively, than for the other regions. Furthermore, outflows to the EU15/EFTA are significantly larger than those to North America, and they also tend to be larger than the deliveries to foreign subsidiaries in Eastern Europe. In sum, the differences in size among the coefficients of outflow show the following pattern: 
EU15 $/$ EFTA $>($ Eastern Europe $=$ North America $)>($ Latin America $=$ Asia $)$.

Thus, in accordance with hypothesis H1, we can observe that the firms in our sample with FDI activities in the region EU15/EFTA on average have small inflows and large outflows, which is evidence for distribution-oriented FDI. Trade inflows from North America are also small, but trade outflows are clearly not as large as those to EU15/EFTA. We may thus conclude that horizontal FDI is, as expected, more common in North America than in EU15/EFTA. Hypothesis $\mathrm{H} 1$ receives further support by the fact that FDI in Asia is of the vertical type, characterized by large trade inflows and small trade outflows. FDI in Eastern Europe and Latin America also seem to be of the vertical type (larger coefficient for trade inflows than outflows). However, this conclusion has to be qualified. Rather unexpected, trade outflows are relatively large in case of Eastern Europe. It seems that Eastern Europe, as a result of the strong economic growth achieved in recent years and in view of the short distance to Switzerland, has been discovered by Swiss firms not only as a favorable location for manufacturing ("vertical FDI") but to some extent also as a promising market for their products ("distribution FDI"). The second qualification refers to Latin America as we observe that trade flows in both directions are smaller than those of Eastern Europe and - less accentuated - those of Asia. Thus, subsidiaries in Latin America seem to be less dependent from their parent companies than foreign affiliates in other regions with vertical FDI; this result is in line with what we found for the variable employment_growth. ${ }^{14}$

Columns (6) to (8) and (9) to (10) of Table 5 contain the findings for Model II for the sub-regions of Eastern Europe and Asia. Disaggregation does not much affect the results for Eastern Europe. In accordance with the results for the aggregated region, large trade inflows (inflow) as well as large trade outflows (outflow) characterize all three sub-regions. More heterogeneous are the results we find for the Asian sub-regions. Whereas the propensity to invest in China or in Southeast Asia/India is positively correlated with the intensity of trade inflows (inflow), the propensity to have FDI in the tiger countries is positively correlated with the intensity of trade outflows (outflow). The differences between the Asian sub-regions discussed in Section 2 thus seem to have consequences for the type of FDI. The relatively rich tiger countries primarily attract distribution-oriented FDI, the low wage costs in the two other Asian sub-regions lead, in the first place, to vertical FDI.

14 FDI activities in Latin America do not affect employment growth of the parent company in Switzerland. 
Table 5: Firm Characteristics by FDI Host Regions; Model II (Intra-Firm Trade Flows); Multivariate Probit Estimates

Notes: See Table 2 for the variable definitions; standard errors are in brackets under the coefficients; ${ }^{* * *},{ }^{* *},{ }^{*}$ denote statistical significance at the $1 \%$ $5 \%$ and $10 \%$ test level, respectively. Estimates are based on 100 draws (change in estimates as the number of draws is further increased is negligible).

\begin{tabular}{|c|c|c|c|c|c|c|c|c|c|c|c|}
\hline & \multicolumn{5}{|c|}{ All regions } & \multicolumn{3}{|c|}{ Eastern Europe } & \multicolumn{3}{|c|}{ Asia } \\
\hline & $\begin{array}{l}\text { EU15/ } \\
\text { EFTA }\end{array}$ & $\begin{array}{l}\text { Eastern } \\
\text { Europe }\end{array}$ & $\begin{array}{c}\text { North } \\
\text { America }\end{array}$ & $\begin{array}{l}\text { Latin } \\
\text { America }\end{array}$ & Asia & $\begin{array}{l}\text { Eastern } \\
\text { Europe }\end{array}$ & $\begin{array}{c}\text { SE } \\
\text { Europe }\end{array}$ & Russia & China & $\begin{array}{l}\text { Asian } \\
\text { Tigers }\end{array}$ & $\begin{array}{l}\text { SE Asia/ } \\
\text { India }\end{array}$ \\
\hline _cons & $\begin{array}{l}-0.946 \\
(1.024)\end{array}$ & $\begin{array}{l}-0.642 \\
(0.744)\end{array}$ & $\begin{array}{l}-3.001^{* * *} \\
(0.778)\end{array}$ & $\begin{array}{l}-2.969^{* * *} \\
(0.820)\end{array}$ & $\begin{array}{l}-2.962^{* * *} \\
(0.763)\end{array}$ & $\begin{array}{l}-1.396^{*} \\
(0.718)\end{array}$ & $\begin{array}{l}-0.201 \\
(0.738)\end{array}$ & $\begin{array}{l}-3.010^{* * *} \\
(0.819)\end{array}$ & $\begin{array}{l}-4.137^{* * *} \\
(0.825)\end{array}$ & $\begin{array}{l}-2.616^{* * *} \\
(0.795)\end{array}$ & $\begin{array}{l}-2.069^{* * *} \\
(0.764)\end{array}$ \\
\hline first_fdi_1990 & $\begin{array}{l}1.006^{* * *} \\
(0.284)\end{array}$ & $\begin{array}{c}0.568^{* *} \\
(0.225)\end{array}$ & $\begin{array}{l}1.138^{* * *} \\
(0.272)\end{array}$ & $\begin{array}{l}0.517^{* *} \\
(0.258)\end{array}$ & $\begin{array}{l}1.153^{* * *} \\
(0.240)\end{array}$ & $\begin{array}{c}0.572^{* *} \\
(0.228)\end{array}$ & $\begin{array}{l}0.486^{* *} \\
(0.247)\end{array}$ & $\begin{array}{l}0.827^{* * *} \\
(0.294)\end{array}$ & $\begin{array}{l}1.184^{* * *} \\
(0.281)\end{array}$ & $\begin{array}{l}1.110^{* * *} \\
(0.294)\end{array}$ & $\begin{array}{l}0.962^{* * *} \\
(0.272)\end{array}$ \\
\hline first_fdi_2000 & $\begin{array}{c}0.491^{*} \\
(0.291)\end{array}$ & $\begin{array}{c}0.009 \\
(0.248)\end{array}$ & $\begin{array}{l}0.959^{* * *} \\
(0.293)\end{array}$ & $\begin{array}{c}-0.059 \\
(0.290)\end{array}$ & $\begin{array}{l}0.747^{* * *} \\
(0.260)\end{array}$ & $\begin{array}{c}0.204 \\
(0.253)\end{array}$ & $\begin{array}{l}-0.027 \\
(0.279)\end{array}$ & $\begin{array}{c}0.239 \\
(0.328)\end{array}$ & $\begin{array}{l}0.980^{* * *} \\
(0.303)\end{array}$ & $\begin{array}{l}0.649^{* *} \\
(0.318)\end{array}$ & $\begin{array}{c}0.493^{*} \\
(0.297)\end{array}$ \\
\hline firm_age & $\begin{array}{c}-0.025 \\
(0.152)\end{array}$ & $\begin{array}{c}-0.086 \\
(0.116)\end{array}$ & $\begin{array}{c}-0.104 \\
(0.117)\end{array}$ & $\begin{array}{c}-0.064 \\
(0.122)\end{array}$ & $\begin{array}{c}-0.064 \\
(0.113)\end{array}$ & $\begin{array}{c}-0.070 \\
(0.110)\end{array}$ & $\begin{array}{c}-0.166 \\
(0.114)\end{array}$ & $\begin{array}{c}-0.038 \\
(0.120)\end{array}$ & $\begin{array}{c}0.034 \\
(0.118)\end{array}$ & $\begin{array}{c}-0.082 \\
(0.118)\end{array}$ & $\begin{array}{c}-0.200^{*} \\
(0.117)\end{array}$ \\
\hline r\&d_intensity & $\begin{array}{l}-0.031 \\
(0.046)\end{array}$ & $\begin{array}{c}0.035 \\
(0.036)\end{array}$ & $\begin{array}{l}0.099^{* * *} \\
(0.037)\end{array}$ & $\begin{array}{c}0.058 \\
(0.039)\end{array}$ & $\begin{array}{c}-0.003 \\
(0.035)\end{array}$ & $\begin{array}{c}0.028 \\
(0.036)\end{array}$ & $\begin{array}{l}0.075^{* *} \\
(0.038)\end{array}$ & $\begin{array}{c}0.021 \\
(0.040)\end{array}$ & $\begin{array}{l}-0.008 \\
(0.037)\end{array}$ & $\begin{array}{c}0.007 \\
(0.037)\end{array}$ & $\begin{array}{c}0.032 \\
(0.036)\end{array}$ \\
\hline tertiary_share & $\begin{array}{c}-0.030 \\
(0.173)\end{array}$ & $\begin{array}{c}-0.252^{* *} \\
(0.123)\end{array}$ & $\begin{array}{c}0.114 \\
(0.126)\end{array}$ & $\begin{array}{c}0.336^{* *} \\
(0.133)\end{array}$ & $\begin{array}{l}0.335^{* * *} \\
(0.123)\end{array}$ & $\begin{array}{c}-0.129 \\
(0.118)\end{array}$ & $\begin{array}{c}-0.207^{*} \\
(0.123)\end{array}$ & $\begin{array}{c}0.060 \\
(0.132)\end{array}$ & $\begin{array}{l}0.335^{* * *} \\
(0.128)\end{array}$ & $\begin{array}{c}0.086 \\
(0.127)\end{array}$ & $\begin{array}{c}0.145 \\
(0.122)\end{array}$ \\
\hline employment_growth & $\begin{array}{l}0.839^{* * *} \\
(0.319)\end{array}$ & $\begin{array}{c}-0.059 \\
(0.223)\end{array}$ & $\begin{array}{c}0.332 \\
(0.245)\end{array}$ & $\begin{array}{c}0.468^{*} \\
(0.251)\end{array}$ & $\begin{array}{c}0.006 \\
(0.230)\end{array}$ & $\begin{array}{c}-0.004 \\
(0.232)\end{array}$ & $\begin{array}{c}-0.148 \\
(0.236)\end{array}$ & $\begin{array}{c}0.025 \\
(0.246)\end{array}$ & $\begin{array}{c}0.145 \\
(0.234)\end{array}$ & $\begin{array}{c}0.090 \\
(0.230)\end{array}$ & $\begin{array}{c}0.008 \\
(0.226)\end{array}$ \\
\hline size & $\begin{array}{l}0.265^{* * *} \\
(0.096)\end{array}$ & $\begin{array}{c}0.147^{* *} \\
(0.060)\end{array}$ & $\begin{array}{l}0.253^{* * *} \\
(0.063)\end{array}$ & $\begin{array}{c}0.158^{* *} \\
(0.065)\end{array}$ & $\begin{array}{l}0.177^{* * *} \\
(0.061)\end{array}$ & $\begin{array}{l}0.166^{* * *} \\
(0.060)\end{array}$ & $\begin{array}{c}0.058 \\
(0.062)\end{array}$ & $\begin{array}{l}0.218^{* * *} \\
(0.064)\end{array}$ & $\begin{array}{l}0.184^{* * *} \\
(0.062)\end{array}$ & $\begin{array}{c}0.137^{* *} \\
(0.063)\end{array}$ & $\begin{array}{l}0.188^{* * *} \\
(0.061)\end{array}$ \\
\hline inflow & $\begin{array}{c}-0.061 \\
(0.051)\end{array}$ & $\begin{array}{l}0.125^{* * *} \\
(0.036)\end{array}$ & $\begin{array}{c}0.015 \\
(0.036)\end{array}$ & $\begin{array}{c}0.060^{*} \\
(0.036)\end{array}$ & $\begin{array}{c}0.084^{* *} \\
(0.036)\end{array}$ & $\begin{array}{l}0.101^{* * *} \\
(0.034)\end{array}$ & $\begin{array}{c}0.056^{*} \\
(0.034)\end{array}$ & $\begin{array}{c}0.080^{* *} \\
(0.036)\end{array}$ & $\begin{array}{c}0.080^{* *} \\
(0.037)\end{array}$ & $\begin{array}{c}0.034 \\
(0.035)\end{array}$ & $\begin{array}{l}0.079^{* *} \\
(0.034)\end{array}$ \\
\hline outflow & $\begin{array}{l}0.185^{* * *} \\
(0.057)\end{array}$ & $\begin{array}{l}0.087^{* * *} \\
(0.029)\end{array}$ & $\begin{array}{l}0.076^{* *} \\
(0.030)\end{array}$ & $\begin{array}{c}0.011 \\
(0.030)\end{array}$ & $\begin{array}{c}0.003 \\
(0.029)\end{array}$ & $\begin{array}{l}0.085^{* * *} \\
(0.028)\end{array}$ & $\begin{array}{l}0.072^{* * *} \\
(0.028)\end{array}$ & $\begin{array}{c}0.072^{* *} \\
(0.029)\end{array}$ & $\begin{array}{c}0.044 \\
(0.029)\end{array}$ & $\begin{array}{c}0.073^{* *} \\
(0.029)\end{array}$ & $\begin{array}{c}0.002 \\
(0.029)\end{array}$ \\
\hline industry & yes & yes & yes & yes & yes & yes & yes & yes & yes & yes & yes \\
\hline $\mathrm{N}$ & & & 334 & & & & 334 & & & 334 & \\
\hline Wald chi ${ }^{2}$ & & & $235.03^{* * *}$ & & & & $102.24^{* * *}$ & & & $124.48^{* * *}$ & \\
\hline $\begin{array}{l}\text { LR test of the multivariate probit } \\
\text { against independent univariate probits }\end{array}$ & & & $198.08^{* * *}$ & & & & $156.10^{* * *}$ & & & $179.24^{* * *}$ & \\
\hline
\end{tabular}




\subsection{Model III: Motives for Production-oriented FDI}

Model III analyzes production-oriented FDI in more detail, in order to get some more insight into the variation across host regions by type of FDI (Table 6). In doing so, we focus on the distinction between regions with vertical FDI and regions with horizontal FDI. In line with hypothesis H1, cost motives (production_cost_motive) are of low relevance for production-oriented FDI in the EU15/ EFTA region and in North America. Production in North America is primarily driven by sales-oriented motives (sales_motive) and, rather surprisingly, the local institutional conditions. However, the latter result becomes plausible when we look more closely to the single motives covered by the (aggregate) variable institutional_motive. The significant effect of this measure is exclusively due to the richer endowment with highly qualified employees in North America as compared with Switzerland.

Hypothesis $\mathrm{H} 1$ is further confirmed by the fact that cost motives are primarily relevant for production in Eastern Europe and Asia, which is additional evidence for vertical FDI in these regions. However, the results also show that a clear distinction between horizontal and vertical FDI is not possible for these regions, as production is also motivated by local sales. While the local market in Asia is primarily served by local production (Model II: small trade outflows), the market in Eastern Europe is served by local production as well as distribution of products exported from Switzerland (Model II: intermediate size of trade outflows). This is intuitively plausible as the average purchasing power is much lower in Asia. Hence, production costs are more important in case of Asia than of Eastern Europe; consequently, the sales of products primarily stem from local production. The large distance to Asia is another factor favoring sales out of local production.

In case of Asia, we get a clearer picture by analyzing the motives at a more disaggregated level. Similar to Model II, we find evidence for vertical FDI in case of Southeast Asia/India (production_cost_motive is dominant). Production in the tiger countries is primarily of the horizontal type (sales_motive is dominant). For China, we observe a mix of horizontal and vertical FDI. In view of the large size and the high growth (potential) of the Chinese market it is not surprising that market-oriented motives are highly important as well.

The drivers of production-oriented FDI in Latin America are unclear. Neither production costs nor sales motives appear to affect significantly the propensity of production-oriented FDI in this region. However, the fact that low production costs are significantly more important as a motive for FDI in Latin America than in the regions EU15/EFTA and North America indicates a certain relevance of vertical FDI. 


\begin{tabular}{|c|c|c|c|c|c|c|c|c|c|c|c|}
\hline & \multicolumn{5}{|c|}{ All regions } & \multicolumn{3}{|c|}{ Eastern Europe } & \multicolumn{3}{|c|}{ Asia } \\
\hline & $\begin{array}{c}\text { EU15/ } \\
\text { EFTA }\end{array}$ & $\begin{array}{l}\text { Eastern } \\
\text { Europe }\end{array}$ & $\begin{array}{c}\text { North } \\
\text { America }\end{array}$ & $\begin{array}{c}\text { Latin } \\
\text { America }\end{array}$ & Asia & $\begin{array}{l}\text { Eastern } \\
\text { Europe }\end{array}$ & $\begin{array}{l}\text { Southeast } \\
\text { Europe }\end{array}$ & Russia & China & $\begin{array}{l}\text { Asian } \\
\text { Tigers }\end{array}$ & $\begin{array}{l}\text { SE Asia/ } \\
\text { India }\end{array}$ \\
\hline _cons & $\begin{array}{c}-0.692 \\
(0.704)\end{array}$ & $\begin{array}{c}0.178 \\
(0.617)\end{array}$ & $\begin{array}{l}-2.651^{* * *} \\
(0.806)\end{array}$ & $\begin{array}{l}-3.202^{* * *} \\
(0.854)\end{array}$ & $\begin{array}{c}-1.137^{*} \\
(0.628)\end{array}$ & $\begin{array}{c}-0.581 \\
(0.606)\end{array}$ & $\begin{array}{c}-0.249 \\
(0.697)\end{array}$ & $\begin{array}{c}-0.876 \\
(0.930)\end{array}$ & $\begin{array}{c}-1.474^{* *} \\
(0.681)\end{array}$ & $\begin{array}{c}-1.365^{*} \\
(0.770)\end{array}$ & $\begin{array}{c}-1.891^{* * *} \\
(0.698)\end{array}$ \\
\hline first_fdi_1990 & \begin{tabular}{|l}
$0.894^{* * *}$ \\
$(0.231)$
\end{tabular} & $\begin{array}{c}-0.034 \\
(0.215)\end{array}$ & $\begin{array}{l}1.220^{* * *} \\
(0.327)\end{array}$ & $\begin{array}{c}-0.019 \\
(0.272)\end{array}$ & $\begin{array}{l}0.582^{* * *} \\
(0.225)\end{array}$ & $\begin{array}{l}-0.018 \\
(0.221)\end{array}$ & $\begin{array}{c}-0.082 \\
(0.266)\end{array}$ & $\begin{array}{c}0.305 \\
(0.404)\end{array}$ & $\begin{array}{c}0.428^{*} \\
(0.259)\end{array}$ & $\begin{array}{c}0.867^{* *} \\
(0.343)\end{array}$ & $\begin{array}{c}0.364 \\
(0.263)\end{array}$ \\
\hline first_fdi_2000 & $\begin{array}{c}0.661^{* *} \\
(0.265)\end{array}$ & $\begin{array}{c}-0.337 \\
(0.254)\end{array}$ & $\begin{array}{c}0.708^{* *} \\
(0.357)\end{array}$ & $\begin{array}{c}-0.313 \\
(0.326)\end{array}$ & $\begin{array}{c}0.500^{*} \\
(0.256)\end{array}$ & $\begin{array}{c}-0.155 \\
(0.259)\end{array}$ & $\begin{array}{c}-0.431 \\
(0.317)\end{array}$ & $\begin{array}{c}-0.121 \\
(0.462)\end{array}$ & $\begin{array}{c}0.319 \\
(0.290)\end{array}$ & $\begin{array}{c}0.734^{* *} \\
(0.370)\end{array}$ & $\begin{array}{c}0.217 \\
(0.300)\end{array}$ \\
\hline firm_age & $\begin{array}{l}-0.143 \\
(0.125)\end{array}$ & $\begin{array}{c}-0.051 \\
(0.105)\end{array}$ & $\begin{array}{c}-0.264^{* *} \\
(0.115)\end{array}$ & $\begin{array}{c}0.018 \\
(0.125)\end{array}$ & $\begin{array}{c}-0.135 \\
(0.102)\end{array}$ & $\begin{array}{l}-0.019 \\
(0.105)\end{array}$ & $\begin{array}{c}-0.157 \\
(0.120)\end{array}$ & $\begin{array}{c}-0.348^{* *} \\
(0.148)\end{array}$ & $\begin{array}{c}-0.137 \\
(0.110)\end{array}$ & $\begin{array}{c}-0.237^{* *} \\
(0.118)\end{array}$ & $\begin{array}{c}-0.168 \\
(0.114)\end{array}$ \\
\hline r\&d_intensity & $\begin{array}{l}-0.045 \\
(0.037)\end{array}$ & $\begin{array}{c}0.085^{* *} \\
(0.035)\end{array}$ & $\begin{array}{l}0.085^{* *} \\
(0.039)\end{array}$ & $\begin{array}{c}0.010 \\
(0.044)\end{array}$ & $\begin{array}{c}0.045 \\
(0.033)\end{array}$ & $\begin{array}{c}0.061^{*} \\
(0.035)\end{array}$ & $\begin{array}{c}0.081^{*} \\
(0.042)\end{array}$ & $\begin{array}{c}0.094^{*} \\
(0.056)\end{array}$ & $\begin{array}{c}0.052 \\
(0.036)\end{array}$ & $\begin{array}{c}0.042 \\
(0.039)\end{array}$ & $\begin{array}{c}-0.002 \\
(0.037)\end{array}$ \\
\hline tertiary_share & $\begin{array}{c}0.051 \\
(0.093)\end{array}$ & $\begin{array}{c}-0.208^{* *} \\
(0.084)\end{array}$ & $\begin{array}{c}0.093 \\
(0.122)\end{array}$ & $\begin{array}{c}0.274^{* *} \\
(0.137)\end{array}$ & $\begin{array}{c}0.107 \\
(0.095)\end{array}$ & $\begin{array}{l}-0.179^{* *} \\
(0.081)\end{array}$ & $\begin{array}{c}-0.183^{* *} \\
(0.090)\end{array}$ & $\begin{array}{c}-0.057 \\
(0.143)\end{array}$ & $\begin{array}{c}0.053 \\
(0.099)\end{array}$ & $\begin{array}{c}-0.002 \\
(0.108)\end{array}$ & $\begin{array}{c}0.087 \\
(0.106)\end{array}$ \\
\hline employment_growth & $\begin{array}{c}0.129 \\
(0.209)\end{array}$ & $\begin{array}{c}-0.121 \\
(0.189)\end{array}$ & $\begin{array}{c}-0.020 \\
(0.215)\end{array}$ & $\begin{array}{c}-0.095 \\
(0.217)\end{array}$ & $\begin{array}{c}0.124 \\
(0.182)\end{array}$ & $\begin{array}{l}-0.209 \\
(0.202)\end{array}$ & $\begin{array}{c}-0.261 \\
(0.243)\end{array}$ & $\begin{array}{c}-0.190 \\
(0.325)\end{array}$ & $\begin{array}{c}0.209 \\
(0.190)\end{array}$ & $\begin{array}{c}-0.056 \\
(0.204)\end{array}$ & $\begin{array}{c}0.028 \\
(0.197)\end{array}$ \\
\hline size & $\begin{array}{l}0.234^{* * *} \\
(0.070)\end{array}$ & $\begin{array}{c}0.088^{*} \\
(0.052)\end{array}$ & $\begin{array}{l}0.285^{* * *} \\
(0.058)\end{array}$ & $\begin{array}{l}0.189^{* * *} \\
(0.064)\end{array}$ & $\begin{array}{c}0.094^{*} \\
(0.051)\end{array}$ & $\begin{array}{l}0.123^{* *} \\
(0.054)\end{array}$ & $\begin{array}{c}0.091 \\
(0.062)\end{array}$ & $\begin{array}{c}0.173^{* *} \\
(0.073)\end{array}$ & $\begin{array}{c}0.113^{* *} \\
(0.056)\end{array}$ & $\begin{array}{c}0.081 \\
(0.059)\end{array}$ & $\begin{array}{l}0.209^{* * *} \\
(0.057)\end{array}$ \\
\hline sales_motive & $\begin{array}{l}-0.008 \\
(0.081)\end{array}$ & $\begin{array}{l}0.192^{* * *} \\
(0.072)\end{array}$ & $\begin{array}{l}0.239^{* * *} \\
(0.084)\end{array}$ & $\begin{array}{c}0.136 \\
(0.095)\end{array}$ & $\begin{array}{l}0.260^{* * *} \\
(0.072)\end{array}$ & $\begin{array}{c}0.138^{*} \\
(0.072)\end{array}$ & $\begin{array}{l}0.316^{* * *} \\
(0.090)\end{array}$ & $\begin{array}{c}0.282^{* *} \\
(0.123)\end{array}$ & $\begin{array}{l}0.325^{* * *} \\
(0.078)\end{array}$ & $\begin{array}{l}0.226^{* * *} \\
(0.087)\end{array}$ & $\begin{array}{c}0.112 \\
(0.080)\end{array}$ \\
\hline institutional_motive & $\begin{array}{c}0.049 \\
(0.083)\end{array}$ & $\begin{array}{c}-0.054 \\
(0.073)\end{array}$ & $\begin{array}{c}0.133^{*} \\
(0.079)\end{array}$ & $\begin{array}{c}-0.009 \\
(0.093)\end{array}$ & $\begin{array}{c}-0.018 \\
(0.071)\end{array}$ & $\begin{array}{l}-0.076 \\
(0.075)\end{array}$ & $\begin{array}{c}0.016 \\
(0.088)\end{array}$ & $\begin{array}{c}0.146 \\
(0.113)\end{array}$ & $\begin{array}{c}0.000 \\
(0.074)\end{array}$ & $\begin{array}{c}-0.004 \\
(0.086)\end{array}$ & $\begin{array}{c}0.029 \\
(0.080)\end{array}$ \\
\hline production_cost_motive & $\begin{array}{c}-0.142^{*} \\
(0.086)\end{array}$ & $\begin{array}{l}0.358^{* * *} \\
(0.079)\end{array}$ & $\begin{array}{c}-0.056 \\
(0.086)\end{array}$ & $\begin{array}{c}0.163 \\
(0.101)\end{array}$ & $\begin{array}{c}0.169^{* *} \\
(0.075)\end{array}$ & $\begin{array}{l}0.303^{* * *} \\
(0.079)\end{array}$ & $\begin{array}{l}0.211^{* *} \\
(0.095)\end{array}$ & $\begin{array}{c}0.124 \\
(0.122)\end{array}$ & $\begin{array}{l}0.263^{* * *} \\
(0.081)\end{array}$ & $\begin{array}{c}-0.043 \\
(0.088)\end{array}$ & $\begin{array}{c}0.145^{*} \\
(0.082)\end{array}$ \\
\hline
\end{tabular}




\begin{tabular}{|c|c|c|c|c|c|c|c|c|c|c|c|}
\hline & \multicolumn{5}{|c|}{ All regions } & \multicolumn{3}{|c|}{ Eastern Europe } & \multicolumn{3}{|c|}{ Asia } \\
\hline & $\begin{array}{l}\text { EU15/ } \\
\text { EFTA }\end{array}$ & $\begin{array}{l}\text { Eastern } \\
\text { Europe }\end{array}$ & $\begin{array}{l}\text { North } \\
\text { America }\end{array}$ & $\begin{array}{l}\text { Latin } \\
\text { America }\end{array}$ & Asia & $\begin{array}{l}\text { Eastern } \\
\text { Europe }\end{array}$ & $\begin{array}{l}\text { Southeas } \\
\text { Europe }\end{array}$ & Russia & China & $\begin{array}{l}\text { Asian } \\
\text { Tigers }\end{array}$ & $\begin{array}{l}\text { SE Asia/ } \\
\text { India }\end{array}$ \\
\hline input_motive & $\begin{array}{l}-0.038 \\
(0.079)\end{array}$ & $\begin{array}{l}-0.008 \\
(0.072)\end{array}$ & $\begin{array}{c}0.094 \\
(0.078)\end{array}$ & $\begin{array}{c}0.010 \\
(0.086)\end{array}$ & $\begin{array}{l}-0.050 \\
(0.069)\end{array}$ & $\begin{array}{c}0.040 \\
(0.074)\end{array}$ & $\begin{array}{c}0.036 \\
(0.086)\end{array}$ & $\begin{array}{c}-0.035 \\
(0.114)\end{array}$ & $\begin{array}{c}0.066 \\
(0.075)\end{array}$ & $\begin{array}{r}-0.026 \\
(0.081)\end{array}$ & $\begin{array}{c}-0.009 \\
(0.078)\end{array}$ \\
\hline industry & yes & yes & yes & yes & yes & yes & yes & yes & yes & yes & yes \\
\hline $\mathrm{N}$ & \multicolumn{5}{|c|}{371} & \multicolumn{3}{|c|}{371} & \multicolumn{3}{|c|}{371} \\
\hline Wald chi 2 & \multicolumn{5}{|c|}{$210.01^{* * *}$} & \multicolumn{3}{|c|}{$86.43^{* * *}$} & \multicolumn{3}{|c|}{$104.25^{* * *}$} \\
\hline $\begin{array}{l}\text { LR test of the multivariate probit against } \\
\text { independent univariate probits }\end{array}$ & \multicolumn{5}{|c|}{$117.50^{* * *}$} & \multicolumn{3}{|c|}{$74.85^{* * *}$} & \multicolumn{3}{|c|}{$92.32^{* * *}$} \\
\hline
\end{tabular}

Notes: See Table 2 for the variable definitions; standard errors are in brackets under the coefficients; ${ }^{* *},{ }^{* *},{ }^{*}$ denote statistical significance at the $1 \%$, $5 \%$ and $10 \%$ test level, respectively. Estimates are based on 100 draws (change in estimates as the number of draws is further increased is negligible). 


\section{Conclusions}

In this paper we aim at characterizing Swiss FDI located in different regions by drawing, at the same time, on firm-specific variables and region-specific characteristics. MNEs can decide to locate FDI in one or more of nine host regions which, in the first place, differ in terms of market-related, cost-related and knowledge related advantages. Three bundles of firm-level variables representing (a) the type of FDI (vertical, horizontal, distribution-oriented), (b) the relevance of FDI experience, and (c) the importance of the firm's capacity to innovate (R\&D intensity, human capital) were employed to characterize the FDI activities in different locations. The paper draws on cross-section data stemming from a survey conducted in the year 2010. As firms may be present in several countries, model estimations are based on the multivariate probit procedure.

Overall, the models used to determine the relationship between the type of $F D I$ and the choice of the host region yielded the expected results. In case of the economically less advanced target regions the results indicate that it is necessary to distinguish between sub-regions; in doing so we get results that are largely in accordance with our expectations. More specifically, we find, firstly, that North America and EU15/EFTA are more likely than other regions to host horizontal FDI, and, secondly, that EU15/EFTA is more attractive than North America for distribution-oriented FDI. Thirdly, in case of less advanced host regions, we find that Eastern Europe primarily receives vertical FDI, but the results also point to some relevance of distribution-oriented FDI; Eastern Europe is thus not only a location for (cheap) production, but FDI in this region are, to some extent, also a means to exploit the potential of this (strongly) growing market. Fourthly, Asia as a whole seems to attract primarily vertical FDI. However a disaggregation of this large area into three sub-regions leads to a more differentiated picture. Horizontal FDI are more common in case of the already highly advanced "tiger countries", whereas Southeast Asia/India as a poorer region mostly receives vertical FDI, and for China, interestingly, we find a mix of vertical and horizontal FDI. It thus turns out that the fast-growing Chinese economy is not only a cheap location for manufacturing but also a significant host country of marketoriented FDI. In case of Latin America the results do not convey a clear picture.

FDI experience, the second group of explanatory variables, primarily affects the level of the global expansion of Swiss MNEs rather than the selection of specific locations.

Finally, we find that the probability of a firm to investing in a certain region is positively correlated with its innovation activities at home; an exception is the 
EU15/EFTA region, probably reflecting the proximity of Switzerland and historical ties. However, the innovation potential of a host region, unexpectedly, is not a decisive factor for attracting FDI of innovative parent companies, expect in case of North America with its particularly large knowledge base.

All in all, the study indicates that an analysis of outward FDI based on detailed information on parent companies and parent-affiliate relationships (intra-firm trade) as well as on some characteristics of host regions can significantly contribute to a better understanding of the location choice of MNEs. 
Table A.1: Descriptive Statistics

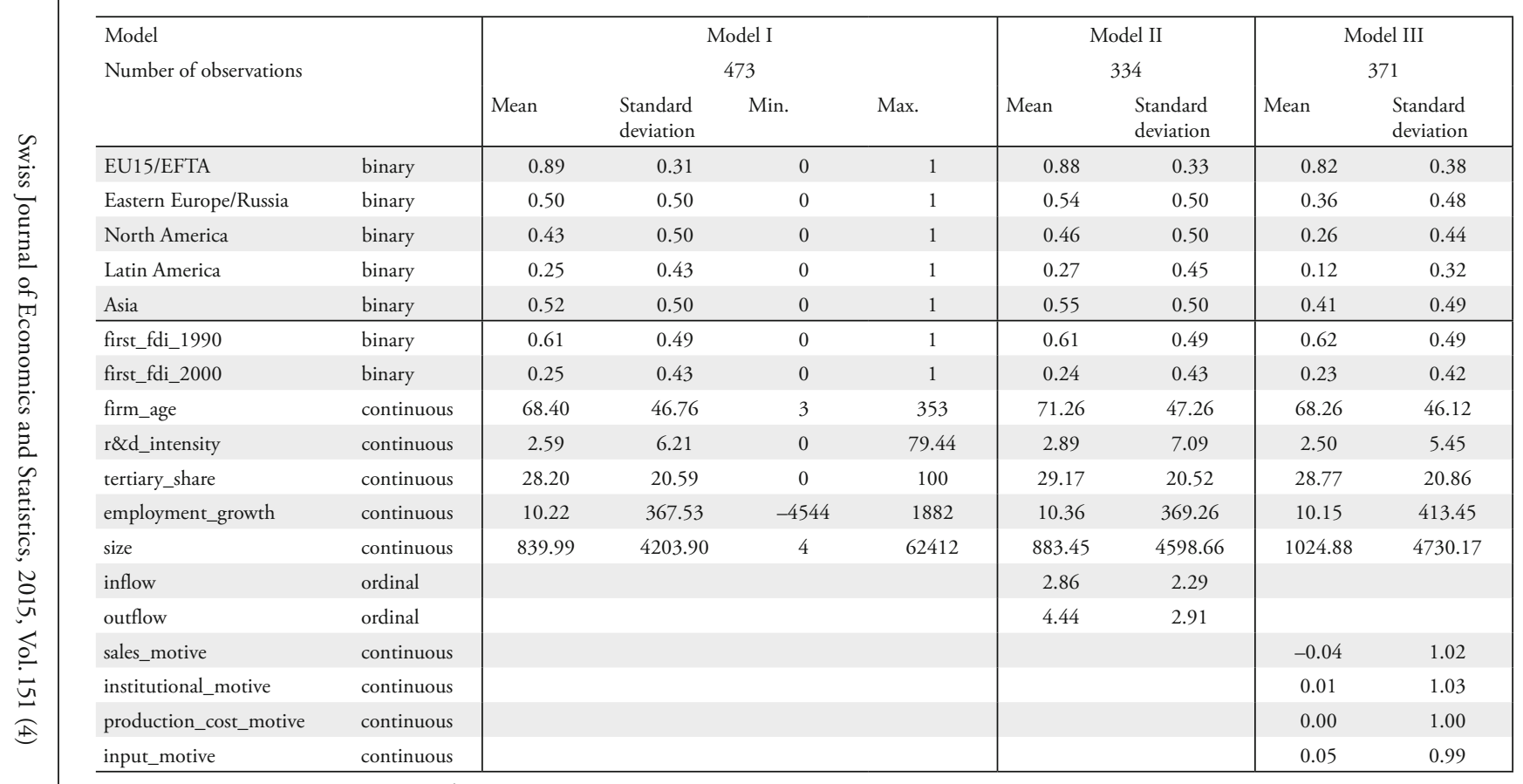

Notes: Information on firm_age, rひd_intensity firm_age, tertiary_share, employment_growth and size are presented in absolute numbers The factor analysis that is used to identify the four groups of motives (sales_motive, institutional_motive, production_cost_motive and input_ motive) contains all observations available. Due to missing values for other model variables, the number of observations that could be used in the regression of Model III is smaller (371 observations compared to 473 in the factor analysis). Therefore, the mean of the factor scores in the regression differs from zero. 
Table A.2: Correlation Matrix (based on Model I; N=473)

\begin{tabular}{|c|c|c|c|c|c|c|c|c|c|c|c|}
\hline & $\begin{array}{c}\text { EU15/ } \\
\text { EFTA }\end{array}$ & $\begin{array}{l}\text { Eastern } \\
\text { Europe }\end{array}$ & $\begin{array}{c}\text { North } \\
\text { America }\end{array}$ & $\begin{array}{c}\text { Latin } \\
\text { America }\end{array}$ & Asia & $\begin{array}{c}\text { first_fdi_ } \\
1990\end{array}$ & $\begin{array}{c}\text { first_fdi_ } \\
2000\end{array}$ & firm_age & $\begin{array}{c}\text { r\&d_ } \\
\text { intensity }\end{array}$ & $\begin{array}{c}\text { tertiary_- } \\
\text { share }\end{array}$ & $\begin{array}{l}\text { employ- } \\
\text { ment_- } \\
\text { growth }\end{array}$ \\
\hline Eastern Europe & 0.036 & & & & & & & & & & \\
\hline North America & 0.110 & 0.379 & & & & & & & & & \\
\hline Latin America & 0.123 & 0.440 & 0.440 & & & & & & & & \\
\hline Asia & 0.004 & 0.433 & 0.485 & 0.493 & & & & & & & \\
\hline first_fdi_1990 & 0.198 & 0.239 & 0.266 & 0.193 & 0.225 & & & & & & \\
\hline first_fdi_2000 & -0.069 & -0.165 & -0.094 & -0.129 & -0.072 & -0.719 & & & & & \\
\hline firm_age & 0.038 & 0.082 & 0.088 & 0.003 & 0.025 & 0.221 & -0.202 & & & & \\
\hline r\&d_intensity & 0.020 & 0.228 & 0.354 & 0.208 & 0.252 & 0.184 & -0.098 & 0.064 & & & \\
\hline tertiary_share & -0.004 & -0.024 & 0.137 & 0.159 & 0.193 & 0.052 & -0.012 & -0.110 & 0.239 & & \\
\hline employment_growth & 0.109 & -0.019 & 0.048 & 0.074 & -0.029 & -0.031 & 0.003 & -0.095 & 0.043 & -0.013 & \\
\hline Size & 0.101 & 0.180 & 0.216 & 0.217 & 0.165 & 0.098 & -0.147 & 0.206 & 0.105 & 0.051 & 0.142 \\
\hline
\end{tabular}


Table A.3: Principal Components Factor Analysis of Motives for Production-Oriented FDI (Rotated Factor Loadings; Factor Pattern Matrix)

\begin{tabular}{|c|c|c|c|c|}
\hline Production & Factor 1 & Factor 2 & Factor 3 & Factor 4 \\
\hline \multicolumn{5}{|l|}{ Motives: } \\
\hline $\begin{array}{l}\text { Using investments as a platform for exports to third } \\
\text { markets }\end{array}$ & 0.19 & -0.02 & -0.04 & 0.03 \\
\hline Securing/gaining market shares & 0.24 & -0.07 & 0.01 & -0.07 \\
\hline Expanding existing markets & 0.26 & -0.02 & -0.11 & -0.03 \\
\hline Main customer is located in target region & 0.22 & -0.01 & -0.01 & -0.13 \\
\hline Main competitor is located in target region & 0.18 & -0.02 & 0.03 & -0.04 \\
\hline $\begin{array}{l}\text { Seeking early market presence to gain competitive } \\
\text { advantages }\end{array}$ & 0.22 & -0.07 & -0.02 & 0.03 \\
\hline Overcoming trade barriers & 0.11 & -0.03 & 0.01 & 0.13 \\
\hline Larger supply of natural resources & -0.03 & -0.02 & -0.14 & 0.49 \\
\hline Larger supply of intermediate products & -0.07 & -0.12 & -0.03 & 0.55 \\
\hline Reducing transportation costs & 0.06 & -0.11 & 0.11 & 0.21 \\
\hline Larger supply of qualified personnel & -0.01 & 0.15 & 0.03 & -0.04 \\
\hline Larger supply of low qualified personnel & 0.00 & -0.06 & 0.30 & -0.06 \\
\hline Lower labor costs & -0.04 & -0.10 & 0.43 & -0.14 \\
\hline Better access to infrastructure services & -0.02 & 0.01 & 0.26 & -0.09 \\
\hline Supplying the parent company at low costs & -0.07 & -0.19 & 0.36 & 0.15 \\
\hline Avoiding CHF currency risk & -0.03 & 0.12 & 0.04 & 0.06 \\
\hline Tax advantages / investment grants & -0.05 & 0.28 & -0.03 & -0.11 \\
\hline More flexible labor market regulations & -0.06 & 0.31 & -0.03 & -0.13 \\
\hline Less strict environmental laws & -0.04 & 0.30 & -0.17 & 0.04 \\
\hline Less restrictive licensing system & -0.06 & 0.39 & -0.20 & -0.05 \\
\hline \multicolumn{5}{|l|}{ Statistics: } \\
\hline Number of observations & 428 & & & \\
\hline Kaiser-Meyer-Olkin measure of sampling adequacy & 0.909 & & & \\
\hline Variance explained by each factor & 3.867 & 3.619 & 2.823 & 1.928 \\
\hline Final communality estimate & 12.237 & & & \\
\hline
\end{tabular}

Characterization of the two factors based on the factor pattern: Factor 1: sales_motive;

Factor 2: institutional_motive; Factor 3: production_cost_motive; Factor 4: input_motive 


\section{References}

Arvanitis, Spyros, Heinz Hollenstein, Marius Ley, and Tobias Stucki (2011), "Die Internationalisierung des Dienstleistungssektors und der Industrie der Schweizer Wirtschaft", KOF Studien, 21, Zürich.

Aw, Bee Yan, and Yi Lee (2008), "Firm Heterogeneity and Location Choice of Taiwanese Multinationals", Journal of International Economics 75(1), pp. 167-179.

Barrios, Salvador, Holger Görg, and Eric Strobl (2006), "Multinationals' Location Choice, Agglomeration Economies and Public Incentives", International Regional Science Review 29(1), pp. 81-107.

Basile, Roberto, Davide Castellani, and Antonello Zanfei (2008), "Location Choice of Multinational Firms in Europe: The Role of EU Cohesion Policy", Journal of International Economics 74(2), pp. 328-340.

Blonigen, Bruce A. (2005), "A Review of the Empirical Literature on FDI Determinants", Atlantic Economic Journal 33(4), pp. 383-403.

Blonigen, Bruce A., and Miao Wang (2005), "Inappropriate Pooling of Wealthy and Poor Countries in Empirical FDI Studies", in Does Foreign Direct Investment Promote Development? T. Moran, E. Graham and M. Blomstrom, eds., pp. 221-243. Washington, DC: Institute for International Economics.

Brainard, S. Lael (1993), "An Empirical Assessment of the Factor Proportions Explanation of Multi-National Sales", NBER Working Papers 4583. Cambridge (MA): National Bureau of Economic Research, Cambridge.

Brainard, S. Lael (1997), "An Empirical Assessment of the Proximity-Concentration Tradeoff between Multinational Sales and Trade", American Economic Review 87(4), pp. 520-544.

Cantwell, John (2008), "Location and the Multinational Enterprise", Journal of International Business Studies 40(1), pp. 35-41.

Cassiman, Bruno, and Reinhilde Veugelers (2002), "R\&D Cooperation and Spillovers: Some Empirical Evidence from Belgium", American Economic Review 92(4), pp. 1169-1184.

CEPII (2010), CEPII geographic data. http://www.cepii.fr/anglaisgraph/bdd/ distances.htm.

Chen, Maggie Xiaoyang, and Michael O. Moore (2010), "Location Decisions of Heterogeneous Multinational Firms", Journal of International Economics 80 , pp. 188-199.

Davidson, William H. (1980), "The Location of Foreign Direct Investment Activity: Country Characteristics and Experience Effects", Journal of International Business Studies 11(2), pp.9-22. 
Demirbag, Mehmet, and Keith W. Glaister (2010), "Factors Determining Offshore Location Choice for R\&D Projects: A Comparative Study of Developed and Emerging Regions", Journal of Management Studies 47, pp. 1534-1561.

Duanmu, Jing-Lin (2012), "Firm Heterogeneity and Location Choice of Chinese Multinational Enterprises (MNEs)", Journal of World Business, 47(1), pp. 64-72.

Duanmu, Jing-Lin (2014), "A Race to Lower Standards? Labor Standards and Location Choice of Outward FDI from the BRIC Countries", International Business Review, 23(3), pp. 620-634.

Dunning, John H. (2000), "The Eclectic Paradigm as an Envelope for Economic and Business Theories of MNE Activity", International Business Review 9(2), pp. 163-190.

Dunning, John H., and Sarianna M. Lundan (2008), Multinational Enterprises and the Global Economy, Elgar: Cheltenham.

Eaton, Jonathan, and Akiko Tamura (1994), "Bilateralism and Regionalism in Japanese and US Trade and Foreign Direct Investment Relationships", Journal of Japanese and International Economics 8, pp. 478-510.

Ekholm, Karolina (1998), "Proximity Advantages, Scale Economies, and the Location of Production", in The Geography of Multinationals, P. Braunerhjelm and K. Ekholm, eds., Dordrecht: Kluwer Academic.

Gazaniol, Alexandre (2014), "The Location Choices of Multinational Firms: The Role of Internationalization Experience and Group Affiliation", The World Economy, doi: 10.1111/twec.12186.

Gassmann, Oliver, and Zheng Han (2004), "Motivations and Barriers of Foreign R\&D Activities in China", R\&D Management 34(4), pp.423-437.

Grossman, Gene M., and Esteban Rossi-Hansberg (2008), "Trading Tasks: A Simple Theory of Offshoring", American Economic Review, 98(5), pp. 1978-1997.

Guimaraes, Paulo, Octávio Figueiredo, and Douglas Woodward (2000), "Agglomeration and the Location of Foreign Direct Investment in Portugal", Journal of Urban Economics 47(1), pp. 115-135.

Hanson, Gordon H., Raymond J. Mataloni Jr, and Matthew J. SlaughTER (2001), "Expansion Strategies of U.S. Multinational Firms", In Brookings Trade Forum, ed. D. Rodrik and S. Collins, pp. 245-294.

Hattari, Rabin, and Ramkishen S. Rajan (2009), "Understanding bilateral FDI Flows in Developing Asia”, Asian-Pacific Economic Literature 23(2), pp. 73-93.

Johanson, Jan, and Jan-Erik Vahlne (1977), "The Internationalization Process of the Firm: A Model of Knowledge Development and Increasing 
Foreign Market Commitments", Journal of International Business Studies 8(1), pp. 23-32.

Johanson, Jan, and Finn Wiedersheim-Paul (1975), “The Internationalization of the Firm: Four Swedish Case Studies", Journal of Management Studies 12(3), pp. 305-322.

Kang, Yuanfei, and Fuming Jiang (2012), "FDI Location Choice of Chinese Multinationals in East and Southeast Asia: Traditional Economic Factors and Institutional Perspective", Journal of World Business, 47(1), pp. 45-53.

Keller, Wolfgang, and Stephen R. Yeaple (2009), "Gravity in the Weightless Economy”, NBER Working Papers 8433. Cambridge (MA): National Bureau of Economic Research.

Kogut, Bruce, and Sea-Jin Chang (1991), "Technological Capabilities and Japanese Direct Investment in the United States", Review of Economics and Statistics 73(3), pp. 401-413.

Le Bas, Christian, and Christophe Sierra (2002), "Location vs. Country Advantages in R\&D Activities : Some Further Results on Multinationals' Location Strategies", Research Policy 31(4), pp. 589-609.

Makino, Shige, Paul W. Beamish, and Natalie Bin Zhao (2004), "The Characteristics and Performance of Japanese FDI in Less Developed and Developed Countries", Journal of World Business 39(4), pp. 377-392.

Mody, Ashoka, Assaf Razin, and Efraim Sadka (2003), "The Role of Information in Driving FDI Flows: Host-Country Tranparency and Source Country Specialization”, NBER Working Papers 9662. Cambridge (MA): National Bureau of Economic Research.

Nachum, Lilach, Srilata Zaheer, and Shulamith Gross (2008), "Does It Matter Where Countries Are? Proximity to Knowledge, Markets and Resources, and MNE Location Choices", Management Science 54, pp. 1252-1265.

Py, Loriane, and Fabrice Hatem (2009), "Internationalization and Location of Services: A Sectoral and Functional Analysis Applied to Multinational Firms in Europe", Économie et Statistique, 426, pp.67-95.

Shatz, Howard J., and Anthony J. Venables (2000), "The Geography of International Investment”, Policy Research Working Paper Series 2338, Washinton D.C.: The World Bank.

Siedschlag, Iulia, Donal Smith, Camelia Turcu, and Xiaoheng Zhang (2013), "What Determines the Location Choice of R\&D Activities by Multinational Firms?", Research Policy, 42, pp. 1420-1430.

SNB (2011), „Kapitalbestand von Schweizer Direktinvestitionen im Ausland 2008“, http://www.snb.ch/de/iabout/stat/statpub/fdi/stats/fdi. 
Transparency International (2008), “TI Corruption Perceptions Index 2008”, http://www.transparency.org/policy_research/surveys_indices/cpi/2008.

UBS (2009), "Prices and earnings 2009", http://www.ubs.com/1/e/ wealthmanagement/wealth_management_research/prices_earnings.

World Salaries (2005), "International Average Employment Income Comparison", http://www.worldsalaries.org/employment-income.shtml.

Worldbank (2010), "World Development Indicators (WDI) and Global Development Finance (GDF)", http://databank.worldbank.org.

\section{SUMMARY}

Based on a unique firm-level dataset for Swiss MNEs, this paper characterizes FDI activities located in different host regions. The characterization of the FDI activities is based on information on the parent companies, their foreign subsidiaries and the two-way trade flows between parent companies and foreign affiliates. Concretely, the study provides econometric evidence based on multivariate probit estimates about the relationship between a firm's choice of nine alternative host regions and the type of FDI (horizontal production-oriented, vertical production-oriented, distribution-oriented), a firm's FDI experience and its capabilities for innovation, respectively. The estimation results indicate that there is low correlation between a firm's capability for innovation and FDI experience, respectively, and the location of their FDI activities. Further, our estimates indicate large heterogeneity with respect to the type of FDI activities. 